\title{
Active audiences and social discussion on the digital public sphere. Review article
}

\author{
Pere Masip; Carlos Ruiz-Caballero; Jaume Suau
}

Nota: Este artículo se puede leer en español en:

http://www.elprofesionaldelainformacion.com/contenidos/2019/mar/02_es.pdf

How to cite this article:

Masip, Pere; Ruiz-Caballero, Carlos; Suau, Jaume (2019). “Active audiences and social discussion on the digital public sphere. Review article". El profesional de la información, v. 28, n. 2, e280204.

https://doi.org//10.3145/epi.2019.mar.04

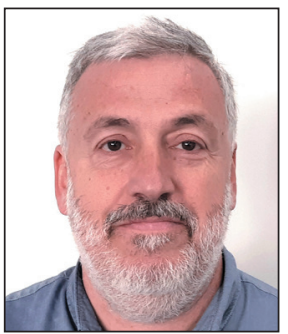

Pere Masip $\square$

https://orcid.org/0000-0002-8231-0824

Universitat Ramon Llull

Facultat de Comunicació i Relacions

Internacionals Blanquerna

$\mathrm{PI}$. Joan Coromines, $\mathrm{s} / \mathrm{h}$.

08001 Barcelona, Spain

peremm@blanquerna.url.edu

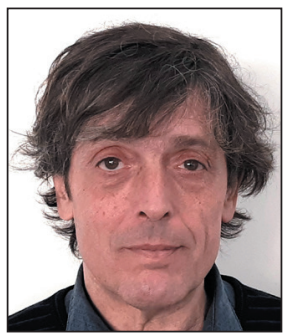

Carlos Ruiz-Caballero

https://orcid.org/0000-0002-1395-2145

Universitat Ramon Llull

Facultat de Comunicació i Relacions

Internacionals Blanquerna

Pl. Joan Coromines, $\mathrm{s} / \mathrm{h}$.

08001 Barcelona, Spain

carlesrc@blanquerna.url.edu

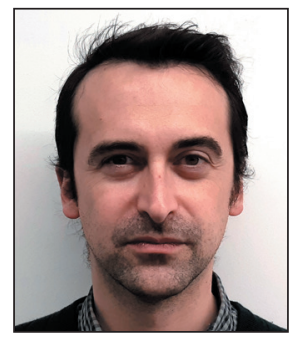

\section{Jaume Suau}

https://orcid.org/0000-0003-4480-4441

Universitat Ramon Llull

Facultat de Comunicació i Relacions

Internacionals Blanquerna

PI. Joan Coromines, s/n.

08001 Barcelona, Spain

jaumesm@blanquerna.url.edu

\begin{abstract}
In little over a decade, essential concepts in research on communication have become zombie concepts (Beck \& Willms, 2004) and are no longer effective for understanding the profound transformation that has taken place with the arrival of the internet. Public sphere, deliberation, audiences, public... the academic literature has oscillated between an initial optimism about the potential for strengthening democracy of communication technologies to a critical scepticism. This text reviews the academic literature with regard to the forms of social deliberation adopted in the context of the media and social networks and its impact on the public sphere.
\end{abstract}

\section{Keywords}

Active audiences; Media; Deliberation; Digital public sphere; Participation; Comments; News sharing. 


\section{Introduction}

In the past, audiences were considered to be those citizens who read the newspaper in a cafe, listened to the radio on the way to work or watched television with their family in the lounge at the end of the day. Media consumption could easily be associated with a particular time and space, often having a certain sense of ritual (Couldry, 2003; Sparks; Tulloch, 2000). Today, the situation is very different. The new nature of audiences is diffuse, but at the same time connected to the day-to-day, which is precisely one of the main features of what Schroder et al. call the multifaceted nature of audiences (Schroder et al., 2003). However, the new media ecosystem has also brought another change or a new dimension with regard to the nature of audiences. According to Livingstone,

“(...) today's media environment is reshaping the opportunity structures by which people (as audiences and as mediated publics) can participate in an increasingly mediatized society" (Livingstone, 2013, p. 24).

Without going into detail yet on the question of whether or not these opportunities for participation are important for democracy, the fact is that a large number of citizens are taking advantage of them. Practices such as commenting, sharing and creating, which are available in any time and space, have become increasingly widespread and are all designed to connect users to each other and/or to media content (Dahlgren, 2013; Jenkins; Ford; Green 2013; Press; Williams, 2010). This new participatory dimension of the nature of audiences adds a new social or relational component that did not appear in previous definitions of audiences (Livingstone, 2013). Therefore, the concept of 'audience' develops characteristics previously attributed to the concept of 'public'.

Audiences, even when conceptualised as active in interpreting texts and messages from the media, have traditionally been understood with regard to their alleged individual and non-deliberative nature (Butsch, 2008) and were not involved in debates on public affairs. Audiences, therefore, were differentiated from the traditional definition of 'public', a concept always associated with deliberation and of a relational nature. As Dahlgren argues,

"atomized individuals, consuming media in their homes, do not comprise a public" (Dahlgren, 2005, p. 149).

However, this distinction between unthinking and disconnected audiences and thinking and participatory publics may be losing validity due to social changes and changes in the media ecosystem (Livingstone, 2005). The idea of the public has always been associated with the media. Habermas (1989) and Tarde (1969) viewed the media (essentially, the press) as sources that provided citizens with information on public affairs. Publics developed in other spaces for participation and meeting, such as cafes, social clubs or squares, where citizens came together, had discussions and exchanged views that led to the formulation of public opinion (Dewey, 1946; Habermas, 1989). As a result, publics and audiences have always been understood as opposite concepts, separated in space and time. Nevertheless, in the new media ecosystem where the media are an essential part of day-to-day life and audiences are becoming more relational and participatory, this traditional distinction between public and audience becomes blurred, as does the separation of public and private space (Papacharissi, 2010).

As a number of authors have pointed out, the current changing media scene is characterised by uncertainty:

"No longer have we clear distinctions between production and reception, between mass and interpersonal communication, or between hitherto distinct forms of media (print, image, music, broadcasting and games, etc.)" (Press; Livingstone, 2006).

The internet is precisely the medium that best represents all these uncertainties and most dramatically highlights the inadequacy of previously important concepts to explain the reality of the media sphere (Williams; Delli-Carpini, 2011).

Of all the concepts and theories that have had to be revised in recent years, one of the most prominent is that of the audience. The term active audiences began to be used precisely in order to distinguish the new nature of
In the new media ecosystem where the media are an essential part of day-to-day life and audiences are becoming more relational and participatory, this traditional distinction between public and audience becomes blurred, as does the separation of public and private space 
the audience (Bruns; Highfield, 2016). Audiences started to be perceived not only as active in the interpretation of journalistic texts and messages but also as active in the sense of production, dissemination of content and public debate in online environments (Suau, 2015). Concepts such as prosumer (Bruns, 2008b) or that of UGC or user-generated content (Thurman, 2008; Singer et al., 2011) identified this new audience perfectly, at the same time a consumer and producer of content, closely connected to the popularity of the first forms of online participation: blogs, wikis and forums. With regard to new terminology, people started to talk about the citizen journalist, and the ease with which users can produce, publish and comment on content. This opened new avenues for discussing the historic hegemony of the traditional media and professionals in the field of journalism (Nerone, 2009; Nip, 2006; Gilmor, 2004). However, in practice, citizen journalism was shown to have limitations and little significance in terms of volume or audience.

Inasmuch as the Internet evolves and new participatory practices develop in the world of journalism and the media, the optimistic discourse linked to the democratisation of information and the greater freedom of citizens predominates (Curran et al., 2012). Often, it is in relation to the concept of the public sphere that the potentially democratising role of active audiences is highlighted (Papacharissi, 2010). However, there have been frequent observations that the early research on active audiences was perhaps over-optimistic (Borger et al., 2013; Lewis; Molyneux, 2018; Quandt, 2018). This realism was the result of multiple empirical studies, which repositioned the role of the active audience and its ability of deliberation in the new public sphere, particularly in two areas:

- comments on the news, and

- the conversation opened up by the expansion of social networks.

Once the low quality of participation had been identified, some studies looked at the facilitating conditions this participation would need to have in order to improve the debate in the public sphere and strengthen democracy, because potentially this was possible (Ruiz-Caballero et al., 2011). That is, ultimately, the aim of this article, which reviews the academic literature on what can be called digital discussion, which extends through comments on the news and in social networks and that adopts new complementary forms that are strongly emerging, such as the sharing of information content that feeds conversation. However, firstly we need to take another look at a central concept that connects audience, information and democracy: the public sphere.

The aim is to establish how the emergence of the internet impacts on Habermas' traditional concept of the public sphere and fragments it and, above all, to understand the transformations it has undergone. And whether or not these transformations enable the function of forming public opinion, the connecting link between public sphere and democracy, to continue to be feasible. To do so, we will review the academic literature in recent years, noting that this review is inevitably influenced by our selection criteria and our own judgment.

\section{Internet and the transformation of the public sphere}

The sociologist Ulrich Beck drew attention to the use by the social sciences of zombie concepts: forms of analysis inherited from the past which are no longer effective for understanding today's world (Beck; Willms, 2004; Rutherford, 2003). We are witnessing another structural transformation of the public sphere (Bruns; Highfield, 2015) driven by the explosion of the internet. For some authors, it follows the Habermasian concept of a unified public sphere where the media exercise a hegemonic role, have mass audiences and act as a space in which the entire public debate plays out is "a convenient fantasy" (Hartley; Green, 2006, p. 347). Other authors believe that this structural change is so radical that perhaps we should consider abandoning the concept (Webster, 2013). A third approach seeks to keep the concept 
alive, but no longer regarding it a single approach and admitting that, at present, the public sphere is comprised of many different spaces (Dalhgren, 2005). We clearly dealing with a zombie concept: it is dead but still alive.

New words have emerged to describe the new existence of the public sphere on the internet: 'digital', 'virtual', 'online.' All these terms share the vision of a communication sphere provided or supported by online social media. In these spaces, participation is open and is available free of charge to all those who are interested, who can discuss matters of common interest through a process that is visible to all (Schäfer, 2015). One of the characteristics which describes this new public sphere is its fragmentation (Galston, 2003). This fragmentation affects both the forums where discussions between citizens can potentially take place and the public.

Bruns and Highfield (2015) provide a detailed and interesting categorisation of the fragmentation. Firstly, there is a wide-ranging divergence of publics. For example, Dahlgren (2009), and Webster (2013) both refer to the political public sphere, while Hartley and Green (2006) describe a cultural public sphere. Obviously, the range is far wider. Another division is technology, where the public is defined by its main medium of communication. For instance, the Twittersphere or the blogosphere have become part of standard language. Along these lines, for example, Benkler (2006) develops the idea of a "networked public sphere". A third fragmentation would be the result of the establishment of temporary publics that emerge and are grouped around a particular theme.

This is what a number of scholars call public sphericules (Gitlin, 1998; Cunningham, 2001; Bruns, 2008a). These authors take the view that the reduced size of the sphere and the shared interest in a subject may improve the

The emergence of the internet impacts on Habermas' traditional concept of the public sphere quality of the deliberation. Another division relates to public issues, spaces for debate on specific topics between all those who are interested. They tend to be about specific events, closely linked to immediacy, in a particular time-frame and fast-moving, which eventually fade away. The latter two types are particularly noteworthy, because they can define the type of spheres that welcome comments on news from readers, as we will see later when we discuss this mode of participation. Networked public sphere would be the correct name for the public subspheres enabled by social networks.

In this new geography of the public sphere, we must be aware of a fuzzy boundary, which affects what is regarded as public, because users move back and forth between personal and public topics. Thus, for example, Schmidt (2014) describes groups of Facebook friends or Twitter followers as ego-centric networks. These are referred to as personal publics. Papacharissi (2010) goes further to talk about the private sphere, where users engage in "privately public conversations" because they are not conducted behind closed doors nor in full view of the public. This is, broadly speaking, the new landscape replacing the old public sphere. Unlike the old sphere, where private individuals expressed views on public affairs, the new public spheres swamp us with messages that can be read in public but only talk to us about personal issues. As opposed to a rational public sphere put forward by Habermas (1989), we find, on that fuzzy boundary, what Papacharissi (2015a) refers to as affective publics. As Bruns and Highfield (2015) state, the emergence of the internet has mixed and merged the individual public spheres that may exist within an increasingly global network with incessant flows of information.

We have seen the types of forums and types of publics that coexist nowadays in the public sphere. We will now examine at their constituent parts. Dahlgren (2005) sets out three constituent dimensions of the public sphere:

- The first is its structural dimension, which relates to its formal institutional features: organisation, financial policy, ownership, control and regulation of the media, as well as the legal framework defining the freedom of communication.

- The second dimension is the representational one and refers to the output of the media, and includes impartiality, accuracy,

- The third dimension is that of interaction. Dahlgren highlights the importance of this dimension and recalls that, both for Habermas and Dewey, publics exist as a process of discursive interaction. For Dalhgren, interaction consists of two aspects. Firstly, it has to do with the citizens' encounters with the media; secondly, the interaction between citizens themselves. On the Internet, civic interaction has taken a major historical step by going online.

There is no doubt that the internet represents an exponential leap in these two types of interaction, both in the potential contacts with the online media and with social networks and all the content distribution platforms, whether for news or entertainment. In addition, it enables types of interaction between citizens that were unimaginable until relatively recently, because it not only enables one-to-one relationships, but also one-to-many, in what Castells (2009) describes as mass self-comunication. This technological option introduces another qualitative element, namely the emergence of other voices that can have an influence and compete with the stories of professional journalists through the content generated by users.

Dalhgren (2005) makes an important warning. The public sphere is not in itself a guarantee of democracy. In the virtual public sphere, there is undoubtedly all sorts of political information and many discussions are taking place, but there must be a structural connection between these communication spaces and the decision-making processes. Otherwise, it may degenerate into a chaotic populism. There needs to be some form of evidence that political conversations between citizens have some influence, some impact. This aspect can be generalised to all of the active audience participation 
through the mechanisms available to them, for example, digital newspapers. Because these mechanisms should not just be a way of attracting customers, without any impact in the media themselves. The audience, in this sense, must have someone who will listen to it. Dalhgren is right when he warns that, otherwise, the citizen may disengage and become cynical.

Dahlberg (2005) also details the conditions for a public sphere. Firstly he clarifies that, when Habermas talks of the public sphere, he is not talking about a specific public, but the whole range of complex networks of different, overlapping publics built up through the critical discourses of individuals, groups, civic associations, social movements and media organisations. What Dahlberg sets out to synthesise are the requirements of an idealised form of public reasoning.

- The first condition is the thematisation and reasoned critique of the validity of problematic claims, which involves the adoption of reasoned opinions.

- The second condition is reflexivity, which implies that the speakers critically examine their values, assumptions and interests in the light of the reasons and statements of others. It also implies that they are willing to change their point of view.

- Thirdly, Dahlberg speaks of ideal role taking. In other words, participants put themselves in the position of all those potentially affected, considering the situation from other perspectives, which involves impartiality and respectful listening.

- Sincerity is the fourth premise. Participants must be honest and alert to deception or self-deception.

- It is also necessary to ensure a formal and discursive equality, where a line of argument is open to all participants affected by the claim under consideration. In addition, there can be no coercion involved.

- Finally, it requires autonomy from the State and financial power. The line of argument developed in the public sphere must be free from the influence of the State or corporate interests.

On the basis of this description, it can be affirmed that, for the public sphere to contribute to the strengthening of democracy, the digital discourse that takes place within it must take these conditions into consideration (Barber, 1984). The key criticisms of this concept of the public sphere point to it being an idealised concept. However, this idealisation is useful in order to critically assess the democratic value of informal day-to-day discussions, although the reality can only be observed in practice.

However, deliberation is only one of the possibilities of the 'digital democracy'. Dahlberg (2011) talks about four digital democracy positions.

1) The first position is what he calls liberal-individualist democracy. Digital media allow individuals to obtain the information they need to examine political positions and problems and give them the opportunity to record, and subsequently include their choices (as public opinion) through a variety of means (e-voting, web feedback systems, e-mail, online polls, etc.). The democratic subject is regarded as a rational individual, self-seeking, a maximiser of instrumental utility, who knows his/her own best interests. They view citizenship as more of an individual than a collective political activity, with the right to pursue one's interests in the marketplace. However, this individual is able to empathise with and support the needs and rights of others. Democracy is perceived as the sum of individual wishes and the competition between representatives to obtain the support of these individuals, as a 'marketplace of ideas'. This approach needs the free transmission of information to allow the individual to make their strategic calculations and choices. The digital media are seen as important, because they are seen to operate reasonably independently of centralised controls.

2) The second position is digital deliberative democracy. Here, the digital media extend a deliberative democratic public sphere of rational communication and formation of public opinion that can hold decision makers to account. Rational deliberation is also identified as taking place, although in a less ideal form, through the texts and commentaries of citizen journalists and 'serious' commentaries in the media. The democratic subject here is not pre-defined as in the previous position but develops from rational deliberation. Private individuals are transformed into democratic subjects interested in the 'common good'. The result is a critical and informed public opinion that can scrutinise the decision-making processes. Democracy, here, is based on the search for consensus, rather than on the sum of individual wills. The digital media and the internet are seen as enablers of this democratic conception.

3) Counter-publics digital democracy is the third position. It emphasises the role of the digital media in the political formation of groups, activism and protest, rather than rational individual action or concerted action after discussion. The democratic subject here arises through engagement in the formation of groups of activism and protest. This is a more affective subject, acting in response to a perception of exclusion or injustice. The subject acts in solidarity with others and the group transcends the individual. 
Democracy is based on two assumptions. The first is that any social formation necessarily involves inclusion/exclusion relationships and associated discursive argument, where the discourse focuses on the meaning that organises social relationships. The second is that this antagonistic situation creates critical spaces to reflect communicative interaction which may challenge dominant discourses and redefine the limits of legitimate communication in the public sphere. In democratic theory, 'counter-publics' are associated with critical theory in the public sphere which views deliberative theory with a degree of sympathy. Although it considers that digital communication technologies support dominant discourses, they also allow excluded voices to be heard and lead to the formation of 'counter-publics' and 'counter-discourses'. The protests on specific issues normally take place in online and offline spaces at the same time. The digital media strengthen the voice of the alternative, the marginalised or oppressed groups.

4) Autonomist Marxist digital democracy is the final position. It sees digital communication networks as enablers of radically democratic politics, i.e. self-organised and inclusive participation that bypasses centralised State and capitalist systems. They can, therefore, contribute to the achievement of an independent and democratic common good. The decision-making process occurs in a collaborative, decentralised manner. Unlike the three previous positions they are not taking part in a project to improve liberal democracy, but it is, rather, about a political revolution which aspires to a new democratic society with a socio-economic agreement based on the common good. This common good is constituted through a decentralized intelligence, on the internet and open source, a 'general intellect". The subject is an autonomous agent, which highlights the difference to working together with others, which is part of the community and yet not limited to it because it is an individual and group identity at the same time. The digital media are potentially seen as enablers of this conception of democracy.

It was felt that the four positions described by Dahlberg should be developed in some detail because, if you read them closely, they latently contain most of the conditions that he himself established for the public sphere. Despite the differences between the positions, in their characteristics, digital democracy in some manner aspires to the ideal. It is also true that, following the very steps of Habermas $(1984 ; 1987)$ in his discursive ethics, each and every one of these conditions can be characterised to understand the distance between the ideal and reality. Let us take, for example, reflexivity, which, as has been shown, implies that speakers should critically examine their values, assumptions, and interests in the light of the reasons and statements of others and are willing to modify their point of view. In this sense, the Internet presents the danger of the fragmentation of audiences in small communities of $\mathrm{li}$ ke-minded people, who do not come into contact with conflicting ideas. As

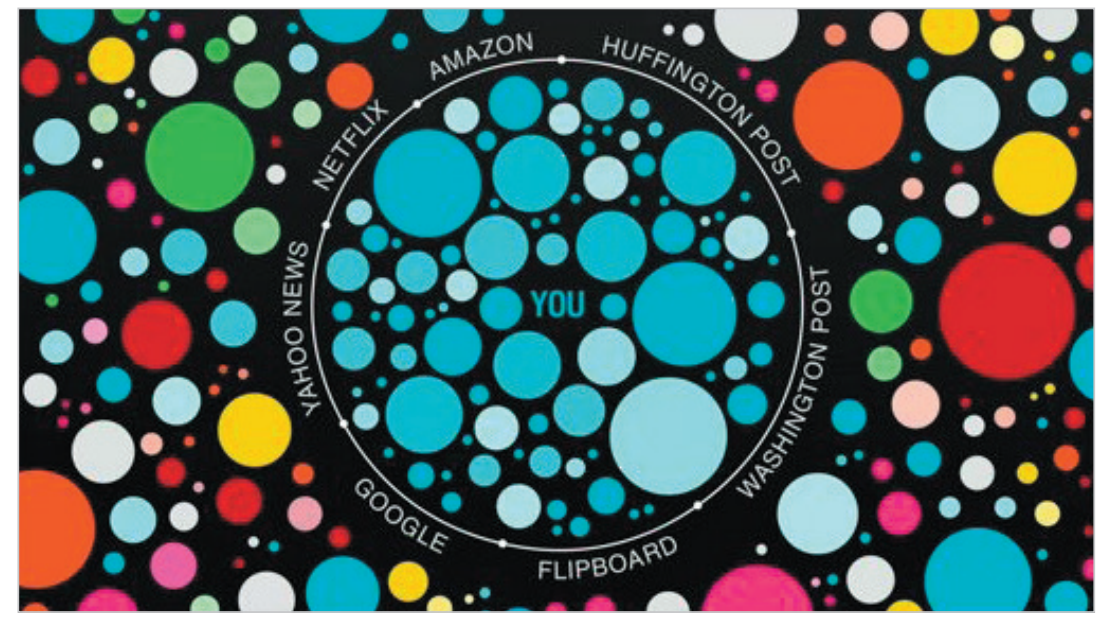

Esquema de burbujas-filtro de Eli Pariser

https://blog.zhdk.ch/aliceschwab/2012/04/19/eli-pariser-beware-online-for-filter-bubbles

\section{Schäfer recalls (2015), this identified}

risk also has a technological aspect. The algorithms of search engines provide users with information that is based on criteria that take into account their behaviour in previous searches, thereby concealing other information. This is what Pariser (2011) calls filter bubbles. The technology itself also makes it possible, on social networks or on media websites, for users to decide who to follow or what content they want to receive. The result is the echo chambers effect: Not only are certain points of view not questioned, but the same points of view are repeated and reinforced in online communities (Sunstein, 2001; 2009); and divergent ideas are thrown out, depriving citizens of alternative views (Bennett; Iyengar, 2008; Iyengar; Hahn, 2009; Del Vicario et al., 2016). There is a risk of creating solo spheres where individual action is tightly restricted by partisanship, and the fragmentation of public debate diminishes the power of citizens and reduces their chances of receiving information and carrying out political actions (Dahlgren, 2013).

Up to this point, the conclusion would be pessimistic. Above all, taking into account the arguments of authors like Sunstein $(2001,2009)$ and Mouffe (2013), who claim that one of the prerequisites for a healthy democracy is the existence of spaces that allow citizens to be exposed to different points of view or perceptions. The problem is not new and it has been addressed in previous decades by the se-

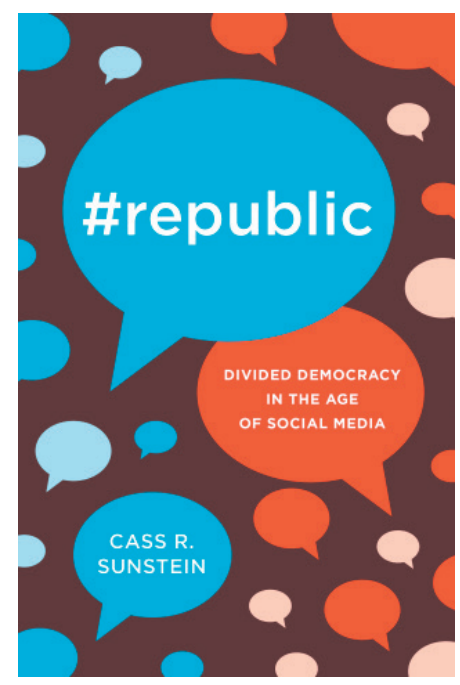


lective exposure theory (Lazarsfeld; Berelson; Gaudet, 1948; Zillmann; Bryant, 1985). The problem re-emerges strongly because technology has increased audiences' control in establishing their own patterns of consumption of information (Brundidge, 2010). Various studies confirm this trend and draw attention to its harmful effects on democratic life (Bennett; lyengar, 2008; lyengar; Hahn, 2009; Sunstein, 2001; Galston, 2002) because, among other reasons, it contributes further to the fragmentation of an already fragmented public sphere. However, this view is questioned by various authors. For example, Curran (2011a; 2011b) highlights the importance of entertainment in shaping individuals' political values due to the difficulty of applying mechanisms of selective exposure in this format. This difficulty also exists in news formats, because they do not always provide partisan information (Webster, 2007). The theory of selective exposure has become more relativised lately because the hybrid media system leads to a cross-media pattern of consumption which makes it difficult to impose a completely selective exposure, even where this is the citizen's intention (Garrett, 2009; Holbert et al., 2010; Chadwick, 2013; Schrøder, 2015).

In other words, the reconfiguration of the public sphere itself and technology lead to contact -desired or notwith other points of view. Some writers hold the view that this positive effect of the internet is limited to the minority of motivated citizens who are interested in politics (Tolbert; Mcneal, 2003; Nisbet; Scheufele, 2004). There is no doubt that there has been a significant shift in the way in which citizens access information. As noted by Stelter (2008), citizens in social networks have now become 'secondary gatekeepers' (Singer, 2013; 2014; Masip et al., 2015) who re-disseminate information and set up a social filter that competes with no longer hegemonic professional filter of journalists and the media. Friends and contacts on social networks share and recommend news (Guallar et al., 2016). Undoubtedly, the affinity between friends and contacts can increase polarisation, but there are scholars who consider that social networks are creating environments in which, under certain circumstances, the citizen is accidentally exposed to information and different points of view, even if they weren't intentionally looking for it (Brundidge, 2010). Several studies (Mitchell; Page, 2014; Mitchell; Holcomb; Weisel, 2016; Masip; Suau; Ruiz-Caballero, 2018) confirm this serendipitous exposure means that the door is kept ajar for pluralism in the consumption of information in the public sphere.

\section{The new citizenship}

Having discussed the concepts of 'digital public sphere' and 'digital democracy', it is appropriate to address the concept of what can be termed the 'digital citizen', a new model of citizenship developed by individuals in the democracies of late modernity (Bennet, 2008; Bennet; Segerberg, 2013). It is a model that is strongly linked to the new communication technologies and with the participatory dimension of the new environment (Papacharissi, 2010; Dahlgren, 2013; Rainie, Wellman, 2012). According to Inglehart (1997), behind the rhetoric and intellectual debates of some postmodernist authors such as Derrida, Baudrillard or Lyotard,

"an empirically demonstrable cultural shift is taking place" (Inglehart, 1997, p. 22).

This cultural shift is identified with changes in the value system and lifestyles of individuals in post-industrial societies and is represented in many different areas, from politics to religion, but also in gender, cultural and sexual trends. When materialistic values emphasised financial and physical security, individuals tended to defend hierarchical and bureaucratic organisations, whereas postmodernist societies tend to adopt values that identify more with the concerns of individual self-expression and quality of life. Accordingly, as Inglehart states (1997), postmodern societies are also characterised by a general decline in hierarchical institutions and rigid social norms, and by the expansion of the realm of individual choice and mass participation. Prominent sociologists have reflected on this new concept of self-identity or self-expression in late modern societies, where individuality takes a leading position in defining the subject. Giddens (1991), for example, points out the 'reflexivity' of the contemporary self, ever-willing to change and adapt to the conditions of the continually changing late modern society. On the other hand, Bauman $(2000 ; 2005)$ maintains that the 'liquid' nature of late modernity implies that the subject struggles to adapt to this changing nature. Rather than the empowered subject found in Giddens' theory, for Bauman, individuality and self-expression of the self are central, but with a permanent condition of ambivalence and uncertainty. Based on these theories, Dahlgren (2013) calls for a review of the ways in which some definitions of the 'civic subject', formerly embedded in the 'intimate realm of life' -such as gender, sexual orientation, etc.- have become politicised issues, as individuals' spheres of action and decision have increased, in line with the new social values. As a result, the boundaries between what is considered public and private are becoming

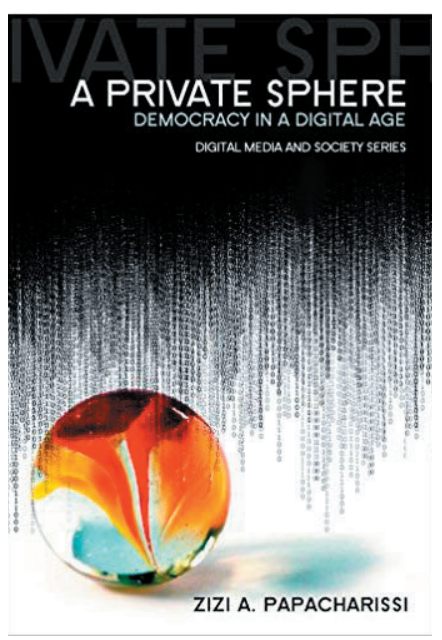


blurred and, as Keane notes (1991), the public spheres are now also expanding into areas of life which were previously immune to controversies about power.

In this context, 'identity politics' emerge (Melucci, 1996), which replace the former hegemony of collective action as the main resource for social movements. In addition, this new 'civic subject' is not attracted by traditional ideologies (or '-isms') and the traditional forms of participation. But instead of being a politically demobilised, disengaged, or disinterested subject, this citizen is politically interested in ways that are not easily captured by aggregated measures, such as polls, and has a political appetite that is not satisfied by "mass-produced content" (Papacharissi, 2010).

This transformation of the subject and their interests has an impact on the concept of the public sphere, which has been fragmented into different micro spheres that develop out of issues that revolve around the self-identification of the subject. These micro spheres are based on communications and everyday life and develop a mosaic of public spheres of different sizes, which overlap and interconnect (Keane, 1991). As Fraser (1992) states, many public spheres co-exist and are formed by counterpublics with different power relationships and represent different groups of self-identification that react in that way to their exclusion from the dominant public sphere. Dahlgren (2013) points out that the weakness of these micro spheres is their disconnection from the traditional decision-making processes which govern society. However, it is precisely this disconnection from the traditional that forces the individuals who make up these public spheres, especially those more connected to politics, to look for alternative channels of expression and dissemination of their positions and discourses. It is in the context of the new public spaces formed around the new media that subjects disconnected from the traditional public sphere can find appropriate channels of expression. The participatory dimension of this new environment helps to improve individuals' spheres of action, creating what some authors regard as a possible new form of citizenship. Various writers have created different concepts to define this new digital citizenship: actualizing citizen (Bennett, 2008; Bennett; Segerberg, 2013), private sphere (Papacharissi, 2010), solo sphere (Dahlgren, 2013) or networked individualism (Rainie; Wellman, 2012). Despite the different terms, they all agree on the influence that the central values of autonomy, control and self-expression of individuals in late modern societies have in relation to the new communication technologies. This new subject and new technologies affect and shape each other, contributing to the creation of something new, that is still liquid, mutable and uncertain. These new models of digital citizenship do not seek to replace the previous traditional conceptualisations of citizenship (Bennet, 2008), but rather they coexist in the new environment.

Bennet takes the view that the 'dutiful model of citizenship', which predominates in many Western democracies, is based on a view of citizenship that considers participation to be a duty of citizens in a democracy. In addition, this participation is viewed in relation to organisations such as political parties, trade unions or other broad social organisations that employ a conventional unidirectional means of communication to mobilise their supporters. On the other hand, the self actualising model of citizenship implies a shift toward a more personalised and individual participation. Voting and collective action become less important, while personalised actions such as volunteering or activism take on greater significance. The previous view of collective action as a duty is transformed into a greater sense of distrust in the traditional institutions, and the close social ties that apply mainly with friends and peer groups become more important (Banaji; Buckingham, 2013).

In her theory of the private sphere, Papacharissi attempts to answer the question as to what extent new 'civic uses' of the Internet convey 'the political', through a digital citizenship that she understands as "civic responsibility empowered by the digital technologies" (Papacharissi, 2010, p. 103). The author accepts that the new environment is creating a new public space, but argues that this new space does not necessarily lead to a new public sphere, because a virtual space simply enhances discussion, while a public sphere enhances democracy. The question then becomes one of whether the new communication technologies could foster democracy, promote rational discourse and also represent equally the diversity of different public spheres of different social players (Papacharissi, 2002). This new public space is not in reality completely 'public', because what is in the centre of all the interactions is the individual. What is leading to the new communication technologies is a private sphere of interaction within which individuals engage socially. And they do so through an environment located in personal and public spaces which, therefore, are interconnected, forming a networked self (Papacharissi, 2010).

Rainie and Wellman (2012) consider that citizens, rather than joining groups, are becoming increasingly networked as individuals. In the world of networked individuals, it is the person who is the focus, rather than the family, the work unit, the neighbourhood, or the social group. However, this does not constitute a world of autonomous and increasingly isolated individuals, but of networked citizens who have access to a series of private spheres that allows them to have relationships and move in areas where they can shape their own complex identities depending on their passions, work interests, hobbies or any other personal characteristic.

Similarly, Papacharissi (2010) holds the view that these individuals are alone but not lonely or isolated. Within the private sphere, the individual cultivates civic habits and connects with others by sharing the same social, political or cultural priorities. According to the author, what has changed with the new communication technologies are the spaces that can convey public action and civic engagement. In the traditional environments, the process of participation in public issues necessarily implied a transition from the personal, or private, to the political, or public. Within the new media en- 
vironment, civic action can be carried out almost anywhere, because citizenship is associated primarily with autonomy, control, and the ability to question authority, and only at a secondary level with the possibility of collective action.

Dahlgren (2013) generally agrees with Papacharissi's configuration of the private sphere, although he prefers to call it the 'solo sphere'. He believes the new digital citizenship should be understood above all as a new habitus for online political participation, a new platform for the civic agency. This new habitus coexists with other traditional forms of citizenship, which actually represent 'high' intensities of participation and engagement, while the solo sphere is a place in which to develop media-centred practices or 'low' intensity forms of political engagement. This takes place within a privatised and networked environment where citizens feel they have more control than in other more contested and committed public spheres. Social networks are the new habitat of this new digital citizen.

\section{The impact of social networks}

The popularisation of social networks from 2004 onwards reactivated the academic debate on the impact of technologies on the public sphere and democracy. As Batorski and Grzywińska note (2018), Twitter and Facebook have been used in social and political movements such as the Arab Spring in Iran, Turkey and Egypt (Bruns; Highfield; Burgess, 2013; Haciyakupoglu; Zhang, 2015; Eltantawy; Wiest, 2011); the protests against SOPA and PIPA in the US (Benkler et al., 2015) and ACTA in Poland (Losey, 2014), and in the Spanish movement of the indignados (Anduiza et al., 2014). Social media have also played an important role in the election campaigns of democratic societies in both developed and emerging countries (Diamond; Plattner, 2012; Persily, 2017; Vergeer et al., 2011).

Social networks have a series of specific characteristics which should be taken into account. For Boyd and Ellison (2007), they have three technical particularities.

- Firstly they allow individuals to construct a public or semi-public profile within a bounded system.

- Secondly, they enable users to draw up a list of other users with whom they share a connection.

- Thirdly, they can look at and search through their list of connections and those made by others within the system.

Boyd, on the other hand, identifies four elements that help to establish a public communication between its users: lists of friends, tools for public comments, profiles and updates based on sequences (Boyd, 2007). This is a set of features that fit with the new digital citizen described above, and a fragmented world of topics and audiences. Several studies have found that political discussions take place in groups of like-minded users, and that meaningful discussions are limited (Sujin; Ji-Young; Woo, 2012; Himelboim et al., 2013; Yardi; Boyd, 2010). Other studies have found evidence of the existence of echo chambers or filter bubbles on Facebook (Robertson et al., 2010; Quattrociocchi; Scala; Sunstein, 2016), and some authors have concluded that individuals very probably exhibit the same behaviour as their friends due to homophily rather than as a result of peer influence (Bakshy et al., 2015). In their study of Facebook, Batorski \& Grzywińska (2018) differentiate two types of communication between users of social networks. The first takes place within networks of friends (semi-private), and the second takes place, in the case of Facebook, on Facebook pages (public). The authors conclude that only a small fraction of Facebook users are active in public political discussions, although they do not view this as due to the configuration of Facebook as a communicative space, but the fact that users prefer to discuss political issues in their private networks of friends and that the main use of Facebook is for entertainment. They also state that the online public on Facebook is fragmented and clustered into homogeneous groups, thus supporting the hypothesis on echo chambers. However, other studies find that the level of filter bubbles reported between Facebook users is low (Bechmann; Nielbo, 2018) and that the incidental news exposure of internet users leads them to access heterogeneous news sources, reducing the effect of selective exposure (Fletcher; Nielsen, 2018; Masip; Suau; Ruiz-Caballero, 2018; Flaxman et al., 2016; Messing; Westwood, 2014).

Brenne (2016) considers that social media can encourage civic engagement in nuanced ways but fail as a public sphere. They fail because continuous surveillance and examination (Foucault, 1977) undermine public opinion. This surveillance, unlike Foucault's panopticon thesis, operates on social networks through desired visibility and the threat of invisibility. This topic is not closed and, in this sense, further studies are required that provide more evidence on the exposure of individuals to information on social networks and, above all, their effect on the formation of their opinion. Perhaps there is a lack of perspective for reaching definitive conclusions on this important aspect of the formation of opinion in the public sphere(s).

Before drawing this academic reflection on the transformation of the public sphere to a close, another fundamental issue must be addressed, which involves another type of fragmentation: that of attention. Because the media compete for the attention of users, and users for the attention of other users. Attention is a limited resource, and in the new media environment has to deal with an ever-increasing number of sources of information, which has led to an 'economy of attention' (Webster, 2011; Davenport; Beck, 2001). Very few issues, people, or groups command the public's attention or the policy agenda for long (Thrall et al., 2008). But this ability to capture the attention is also a skill of the users of social networks, who have added the logic of trending (Van-Dijk; Poell, 2013). According to Webster and Ksiazek (2012), the most obvious cause of this fragmentation is the constant growth in the number of media and products that are competing for public attention, with the emergence of the internet as a key factor. They believe that, unfortunately, the supply of public attention is limited and, given the endless number of demands, scarce. For this reason, many authors have 
characterised the era of information as an 'economy of attention', because attracting an audience is a prerequisite for achieving economic, social or political objectives (Davenport; Beck, 2001; Goldhaber, 1997; Lanham, 2006; Webster, 2010). This is the logic of the hybrid media system and, as it is applied constantly, fragments the audience time and time again.

The issue of attention concerns Habermas. He considers that the web itself does not produce a public sphere because its structure is not suited to attracting the attention of a public of scattered citizens who form opinions simultaneously on the same problems, and whose contributions have neither been scrutinised nor filtered by experts (Jeffries, 2016). In terms of the social networks, Habermas believes that they open up new possibilities for organising activities and for large-scale mobilisations of widely scattered individuals. However, these individuals continue to depend on their relationship with the real decision-making processes that take place outside the virtual space (Jeffries, 2016). The German philosopher believes that the traditional public sphere arose from the fact that the public's attention was focused on a number of important political issues that needed to be regulated. On the contrary, the internet actually "distracts and dispels" that attention (Schwering, 2014). Thus the internet becomes a plethora of "digital noises" where there are countless communities that are actually scattered communicative archipelagos. What the online communication spaces lack, according to Habermas, is an inclusive bond,

"the inclusive force of a public sphere highlighting what things are actually important." (Schwering, 2014).

For this reason, he believes that the capabilities of good traditional journalism are imperative. Jeffries (2016) explains that, when he interviewed him, Habermas was concerned about the risk of obsolescence of the newspapers due to the Internet boom. He was worried because the national press, which had acted until then as the backbone of democratic discourse, was in danger since nobody had found a financially viable solution to guarantee the survival of the most important national newspapers on the internet. Without naming it Habermas raises the issue of disintermediation. As stated by Fisher (2017), politicians are increasing their use of social media to communicate directly with voters and, on the other side, internet users are equally keen to consume information directly from politicians or their parties, without it being filtered or edited by news professionals. This possibility of being able to reach the audience without the mediation of the media erodes one of the essential functions of the press in a democracy: that of the 'watchdog' (Fisher et al., 2019; Broersma; Graham, 2013). Let us take as an example president Donald Trump's use of Twitter, who categorises news stories published by the media who are critical of his management as 'fake news'.
Habermas believes that they open up new possibilities for organising activities and for large-scale mobilisations of widely scattered individuals. However, these individuals continue to depend on their relationship with the real decision-making processes that take place outside the virtual space

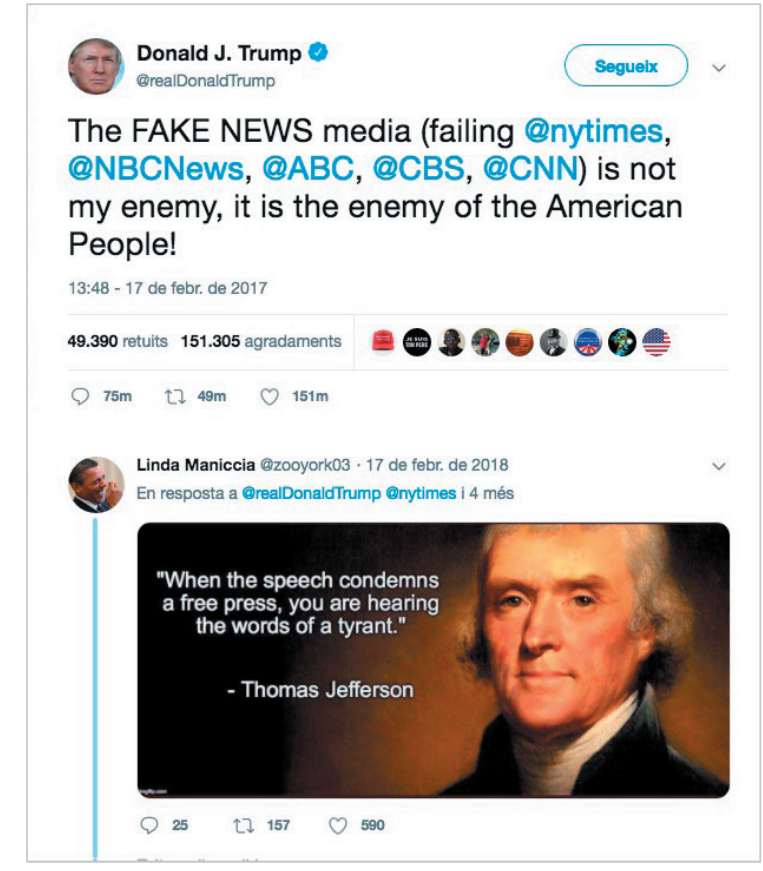

Tweet of Donald Trump attacking the media that criticize him

In addition, disintermediation makes it possible for false news to thrive, because information can travel from the producer of the content to the audience without any filter (Cooke, 2018). This aspect of disintermediation is important because, as Dahlgren states (2005), to be considered public from the point of view of the public sphere, there must be a process of discursive interaction. He considers that this interaction consists of two aspects. The first is the citizens' encounters with the media - the communicative processes of making sense, interpreting, and using the output. The second aspect of interaction is that between citizens themselves, which can include anything from conversations between two people to large meetings. Disintermediation directly affects the first aspect, leaving the information that circulates without an interpretive framework or, in other words, leading to any interpretation.

This may be lacking in perspective and more empirical studies may be required. The real impact of the press on the public sphere could not be envisaged to its full extent until two centuries later. In any case, Habermas's perspective must be re-examined. In his approach there is an inescapable question: that of rational deliberation. Dahlgren (2005) notes two basic conceptual difficulties in Habermas' vision of discursive rationalism. The first is that, in his understanding, the rationalist bias tends to discount a wide array of communicative modes that can be of importance for democracy, including the affective, the poetic, the humorous or the ironic. The second is that adherence to the perspective of deliberative democracy risks downplaying relations of power that are built into communicative situations. For this reason, Dalhgren proposes to address the political discussion not only in terms of their rational communicative qualities, but 
also through his notion of civic culture (Dalhgren, 2000a; 2000b; 2003). Its most fundamental practice is civic interaction, and discussion. From this vantage point, discussion may not always take the form of Habermasian deliberation, because through participation, people are exploring new ways of being citizens and doing politics, such as the sharing of information. However, Dalhgren recognises that discussion may take the form of deliberation and that talk among citizens is the catalyst for the civic cultures that are fueling this engagement. Calhoun's observation (1992) is of interest, when he criticises the fact that to affirm that there are many public spheres leaves us disoriented in the search for a new term to describe communicative relationships between them. He suggests that it might be more productive to think of the public sphere as involving a field of discursive connections. Despite all the criticisms of the Habermas concept of public opinion, discourse and deliberation they are still, to some extent, present in the reflections on the public sphere in the internet age. Because, as Calhoun states (1992), a public sphere appropriate for a demo-

The possibility of being able to reach the audience without the mediation of the media erodes one of the essential functions of the press in a democracy: that of the 'watchdog' cratic policy depends both upon the quality of discourse and the quantity of participation. In the words of Habermas himself (2006), must democracy have an epistemic dimension? If the answer is yes, the public sphere must somehow be a 'space of reasons', where there is at least some intention to have a discussion and listen with respect to others' points of view. And the digital media have a responsibility to provide the conditions to make that possible when they themselves become public spheres/sphericules. In this case, for example, for readers' comments on the news. A minimally rational deliberation is possible, as has been demonstrated in several studies (Ruiz-Caballero et al., 2011). Habermas buried his concept of the public sphere with his own hands, but the concept is still alive. Its own critics breathe life into it, constantly. Perhaps it is because, despite everything, democracy needs a citizen with a minimal epistemological dimension. Let us then examine the digital deliberation that is conveyed through the comments on news and in social networks and if it displays this dimension in any way.

\section{Digital deliberation: from Habermas to Zuckerberg}

Posting comments on the news is one of the most popular forms of user participation generated by the most popular online media (Graham; Wright, 2015; Reich, 2011; Springer, 2014; Weber, 2014; Stroud et al., 2014; Ziegele, 2016). Although, as shall be discussed below, some media outlets have excluded or limited their use, they are still the most widespread form of participation (Santana, 2011; Suau; Masip, 2014; Suau, 2015). However, in a broad sense, it can be seen that the deliberative function of comments has been moved to other digital spaces, particularly Facebook (Su et al., 2018; Rowe, 2015) and Twitter (Boyd; Golder; Lotan 2010), and more recently to closed spaces such as messaging apps (Goh et al., 2017).

Just over ten years ago, the media discovered the possibilities that participation offered them for engaging the audience and potentially bringing it into the productive process, especially as a source. Much of the research carried out during the last decade has focused on the study of the impact of the comments (Singer, 2010), social networks (Hermida, 2010; 2013; Hermida; Lewis; Zamith, 2014; Broersma; Graham, 2013), the UGC (Manosevitch; Tenenboim, 2017; Naab; Sehl, 2017), journalistic routines or the role of citizens as disseminators of journalistic information (Coddington; Holton, 2014; Vos; Heinderyckx, 2015; Guallar et al., 2016). In general, journalists have shown little interest in interacting with the audience (Herrera-Damas; Hermida, 2014) and have used participatory mechanisms to promote their own work or that of the organisation they work for (Vis, 2013; Armstrong; Gao, 2010; Lasorsa; Lewis; Holton, 2012; Russell et al., 2014; Chorley, Mottershead, 2016; Malik; Pfeffer, 2016).

As mentioned above, conversation and exchange of views on public affairs are a central element in democracies (Dewey, 1946). The existence of spaces to exchange views and the richness of these conversations illustrate the quality of democracy. Steiner sums it up when he states:

"Europe is made up of cafés" and that "the café is a place for assignation and conspiracy, for intellectual debate and gossip, for the flâneur and the poet or metaphysician and his notebook. It is open to all, yet it is also a club, a freemasonry of political or artistic-literary recognition and programmatic presence" (Steiner, 2004, p. 17).

Two hundred years after the appearance of these cafés which Steiner describes, our attention is turned to the internet, Web 2.0 and social networ-

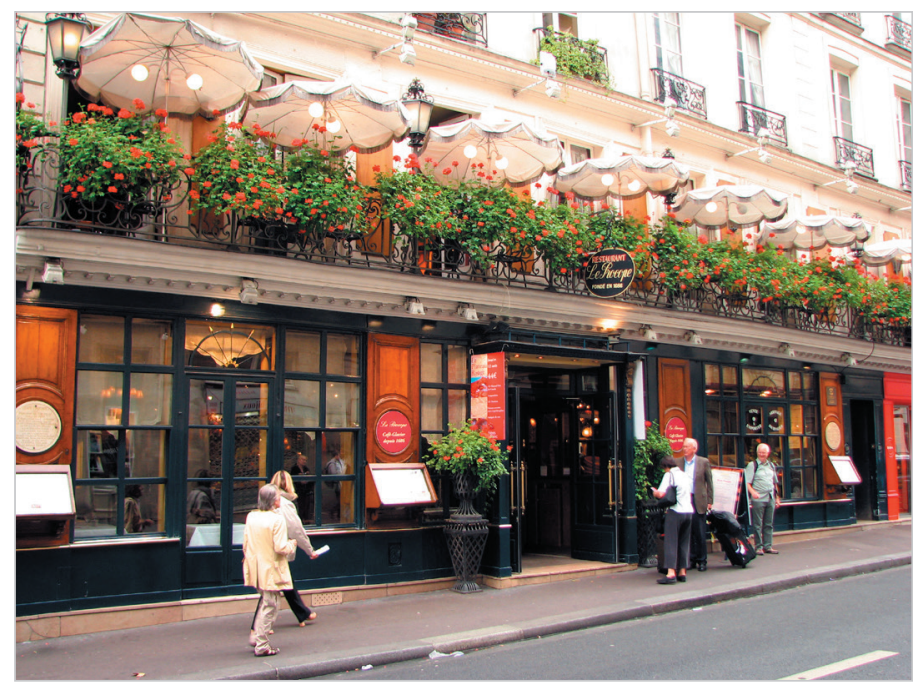

Café Procope, Paris 
ks, which raises the question: Are they the cafés of the $21^{\text {st }}$ century? The academic studies that have sought to provide an answer to that question are reviewed below, especially those that have considered that the spaces provided by the media for comments, and subsequently social networks, could exercise play that role of a public agora.

A good proportion of the initial academic work on participation through the media assumed that the internet and its interactive capacity would bring about a rejuvenation of democracy. This approach finds its roots in the liberal thinkers of the 19th century and in the normative concept of journalism (Wahl-Jorgensen; Hanitzsch, 2009; Kovach; Rosenstiel, 2001). Borger et al., (2013) found that exaggerated optimism about the potential for democratisation is already flourishing in the early work on participatory journalism and interactivity (Deuze, 2001; Massey; Levy, 1999; Singer, 1998; Domingo et al., 2008; O'Sullivan; Heinonen, 2008). However, these studies characterised by optimism, soon gave way to others which, on the basis of empirical research, showed less enthusiastic results. The Dutch researchers identified three reasons for disappointment: disappointment with professional journalism's obduracy, disappointment with journalism's economic motives to facilitate participatory journalism and disappointment with news users' passivity. As shall be discussed below, a good proportion of this disappointment emerges after analysing the role of comments and social networks as spaces for debate on current affairs driven by the media.

Initially, comments, and later social networks, offered readers the opportunity to express their views on public issues and adopt an active attitude that went beyond the traditional passive role assigned to the audience. From a normative perspective, the spaces for comments, either in the media themselves, or in their respective Facebook pages, have characteristics that make them potentially favourable environments for deliberative discussion (Ruiz-Caballero et al., 2011; Prochazka; Weber; Schweiger, 2018; Oz; Zheng; Chen, 2018). This deliberative capacity is not only displayed through making comments, but also through reading the comments (Springer; Engelmann; Pfaffinger, 2015) and, as discussed, by sharing news, which provides a framework for the conversation (Swart; Peters; Broersma, 2018). Thus, Ruiz-Caballero et al. (2011) observed how in the British or North American media the spaces for comments constitute spaces of public discussion, in which diverse views were welcome, based mainly on arguments and respect between the participants. These characteristics, however, were not shared by media in other media systems (Ruiz-Caballero, et al., 2011; 2010).

Despite the potential offered by the comments section, some authors remain sceptical, especially with regard to the lack of respect that characterises some comments and the tendency towards homophily (Santana, 2013; Anderson et al., 2014; Coe; Kenski; Rains, 2014). To understand this scepticism, we need to go back to the elements that characterise Habermas's discourse ethics $(1998 ; 2003)$ and give validity to discourse: intelligibility, truth, veracity and honesty. For the German thinker, dialogue is a rational ethical procedure for social construction. However, for dialogue to effectively be an ethical procedure, it must be previously accepted that all the people involved are considered to be valid interlocutors, i.e. they recognise each other as people and they are able to understand each other through communication. In this case, if readers recognise and respect each other in a dialogue and exchange of points of view, there would be no place for insults or disqualifications between them, or from the readers towards other stakeholders related to the news (actors, people or institutions involved, journalist who has written the news story, media, etc.).

One of the main concerns about the spaces of digital deliberation is that they open the door to incivility. Incivility is an ambiguous concept, open to multiple interpretations. The Oxford Dictionary defines it as "rude or unsociable speech or behaviour", but the decision as to what behaviour is regarded as sociable or unsociable depends on each individual. Likewise, you can establish degrees of severity of rude behaviour. In any case, incivility brings nothing positive in that it does not recognise the mutual respect between speakers (Brooks; Geer, 2007) which as discussed is required for deliberation. Papacharissi (2004) distinguishes between impoliteness and incivility, although both are closely linked. Impoliteness refers to behaviour that contradicts the rules of

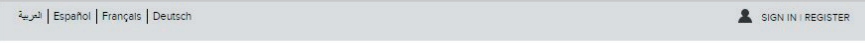

\section{FIRST DRAFT}

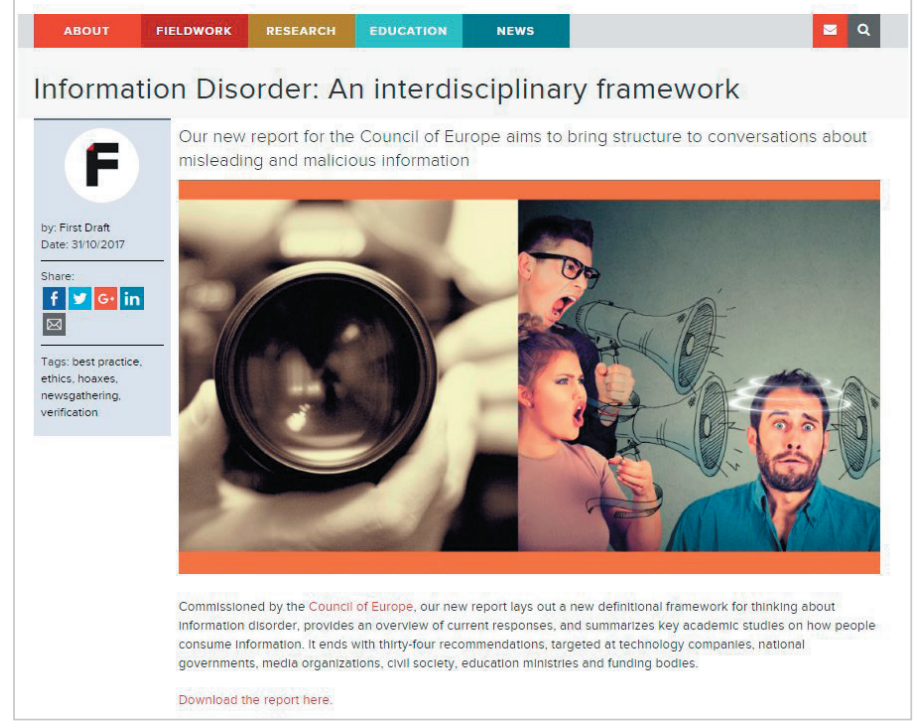

https://firstdraftnews.org/coe-report 
etiquette, whereas incivility implies a greater degree of severity, in that its presence undermines democracy and individual freedom. Coe, Kenski \& Rains (2014), in their proposal for operationalisation, identify five forms of incivility: name-calling, aspersion, lying, vulgarity, and pejorative for speech.

Although it is not widespread, impoliteness is present in most conversations ${ }^{1}$ (Ruiz-Caballero et al., 2011; Coe; Kenski; Rains, 2014). However, it is much more worrying in the presence of incivility. Various studies agree in identifying the habitual presence of comments that show disagreement with the views of others, denying and disrespecting the legitimacy of the opposing views (Hwang; Kim; Kim, 2018; Ruiz-Caballero et al., 2011), or hate speech against minorities, women (Edstrom, 2016) or against journalists (Nilsson; Örnebring, 2016).

The behaviour described above is a matter of concern, as it has a negative impact on democratic values and favours polarisation of opinions (Anderson et al., 2014). Authors like Sunstein (2002; 2017) are especially critical, not only of the online discussions, but also with other forms of interaction, such as customisation. Sunstein warns that the internet results in a substantial reduction in the interactions between citizens, thereby reducing diversity and pluralism and consequently a homogenisation from the point of view of interest and opinions, i.e. the echo-chambers discussed above. The result is polarisation, and individuals tend to adopt more extreme positions than they held previously. Although, as we will discuss below, various studies provide a more nuanced insight into Sunstein's words, there is certainly no shortage of work to support the theory of confirmation bias, through which people interpret information in line with previous beliefs, referring to sources that support them and ignoring those sources that would refute them or challenge them (Nickerson, 1998; Stroud, 2010; Muddiman; Stroud, 2017). Thus, Steinfeld, Samuel-Azran \& Lev-On (2016) noted how readers were openly cynical with users who questioned their pre-existing points of view, and that, in general, exposure to disagreement is limited (Zhou; Chan; Peng; 2008). Although users tend to believe that they act autonomously, evolutionary, cognitive and neurological phenomena and other adaptive and unconscious mechanisms induce them to confirm their own convictions and to reject the contrasting information (Sharot, 2017; Bargh, 2017; Shermer, 2011).

In the context that we have described, this, in addition to increasing the illusion of certainty, causes polarisation, extreme identification with the group and lack of diversity. Various authors state that spaces for discussion reinforce homophily (Dvir-Gvirsman, 2017; Trilling; Van-Klingeren; Tsfati, 2016). Other research examines the pessimistic point of view in more detail and offers some hope on the role that the public sphere may eventually develop (Ruiz-Caballero et al., 2011; Camaj; Santana, 2015; Oz; Zheng; Chen, 2018). The degree of polarisation depends on the topics of discussion. While there are heavily ideologised topics in which alternative viewpoints are scarce, in other apparently nonpolitical topics, discussion takes place among individuals who differ in their political opinions (for instance, regarding the Boston Marathon bombing, the Super Bowl or the Winter Olympics (Barberá et al., 2015).

The number and quality of the comments, and especially their incivility, are conditioned by various contextual variables. In general, news on the more controversial issues attracts more comments (Boczkowski; Mitchelstein, 2012; Weber, 2013; Tenenboim; Cohen, 2015; Ruiz-Caballero et al., 2010; Ziegele et al., 2017). The predominant role of politics as the main topic which provokes comments appears repeatedly in the academic literature (Richardson; Stanyer, 2011; Boczkowski; Mitchelstein, 2012; Tenenboim; Cohen, 2015). Coe, Kenski \& Rains (2014) found that news stories on certain subjects were more likely to receive disparaging remarks. In particular, political, economic and international news received one uncivil comment for every four comments posted, whereas the proportion is considerably lower in the 'soft news' topics such as health, lifestyle, or technology. The exception to this is sports, which provoke a significant level of incivility. Consistent with this, Oz, Zheng \& Chen (2018) warned that discussions on more sensitive issues, which they defined as those with a heavy moral content, contain greater incivility and impoliteness. These issues, however, were also those that had a greater number of deliberative attributes. A study of 42 US news outlets' Facebook pages over an 18-month period showed that the civility of the readers' comments varied according to the ideological stance of the media and the typology. Conservative news outlets and local media were more likely to receive uncivil comments than the liberal news outlets and the national media (Su et al., 2018).

In addition to the topic, the sources used can also influence incivility. For example, a study of more than 300 articles and 6,400 comments published on a US newspaper website, found that the articles that contained a quotation from President Obama received more uncivil comments than those that did not contain one (Coe; Kenski; Rains, 2014). In general, content that is regarded as more biased, due to the lack of inclusion of sources, has more hostile remarks than content that contains a greater variety of sources (Ksiazek; Peer; Zivic, 2015; Ksiazek, 2018).

The tone of the comments can also influence readers' opinions on a specific topic, particularly of those users who are less interested in the topic discussed (Winter; Krämer, 2016), due to people's fear of isolation. The readers of comments can modify their view of a particular topic by moving it towards what is perceived to be the majority of public opinion (Lee; Jang, 2010; Anderson et al., 2014; Hsueh; Yogeeswaran; Malinen, 2015). In general, users are more likely to ex- 
press their opinion when it is in agreement with the majority (Soffer; Gordoni, 2017; Chen; Lu, 2017), which leads to a real lack of debate, a dialogue of the deaf (Ruiz-Caballero et al., 2011).

Ziegele et al., (2018) and Heinbach, Ziegele \& Quiring (2018) found that constructive comments generated greater interest in the article they related to, while aggressive comments caused in turn equally aggressive replies (Chen; Lu, 2017; Gonçalves, 2018; Ziegele et al., 2017), including comments that were politely expressed but expressed disagreement with the majority opinion (Chen; Lu, 2017). Aggressiveness, therefore, provokes greater aggressiveness, but far from this being a source of discouragement, a number of studies have shown that it encourages greater participation and longer visits (Steinfeld; Samuel-Azran; Lev-On, 2016; Bakker; Pantti, 2009). On the other hand, the findings of Springer, Engelmann \& Pfaffinger (2015), suggest that low-quality comments act as inhibitors of participation.

The increase in participation, the number and length of visits would be in line with the media's strategic objectives for these spaces for participation and comments (Domingo et al., 2008; Nilsson; Örnebring, 2016; Vujnovic et al., 2010), and would illustrate the second disappointment described by Borger et al. (2013) regarding the momentum of the media's participatory options: disappointment with the financial motives of journalism in facilitating participatory journalism. Readers are also aware of the media's financial motivations for reader participation (Steinfeld; Samuel-Azran; Lev-On, 2016; Masip et al., 2015b).

In spite of this financial logic, there is a concern about the negative impact that comments could have on the image of the media, and on the audience's perception of the quality of the news (Anderson; Brossard; Scheufele, 2012; Hsueh; Yogeeswaran; Malinen, 2015) and the journalistic practice itself (Hermida; Thurman, 2008; Braun; Gillespie, 2011; Prochazka; Weber; Schweiger, 2018; Domingo, 2018). Consequently, some media have decided to close their spaces for comments (CNN, Bloomberg, Reuters, Chicago Sun-Times...) (Masip, 2011). The way forward to address these problems is to devote more time and attention to comments, despite the objections expressed by some journalists (Robinson, 2010; Reich, 2011; Mitchelstein, 2011; Bergström; Wadbring, 2015).

The undeniable potential of digital deliberation requires a rethinking of these spaces so they can be effectively used. This was the conclusion of various recent studies, which advocate a redesign of the spaces that improves usability and quality interaction, and the introduction of effective mechanisms for moderation (Zamith; Lewis, 2014). On this point, several studies (Karpowitz; Raphael, 2014; Wright; Street, 2007) state that the design should be conducive to fostering discussion and that, under the right conditions, well-designed spaces can lead to deliberation aimed at sharing reasoned and well-informed opinions.

Through experimental studies, Peacock, Scacco \& Stroud (2017) showed that the design of the space allocated for the comments and the information that goes with them can increase the willingness to comment. A structure where conflicting views are clearly identified favours the posting of more comments. The inclusion of multimedia content also leads to greater participation (Ksiazek, 2018), although it does not affect its quality (Liu; Zhou; Zhao, 2015).

Although they are in a minority, various studies that have compared the behaviour of readers on different platforms, have detected different behaviour. Thus, for example, Oz, Zheng \& Chen (2018) noted that posts responding to the White House's tweets were significantly more uncivil and impolite and less deliberative than responses to White House Facebook posts. However, a study comparing the news comments on political news between The Washington Post site and the Washington Post Facebook page found that comments on the news site were more likely to be relevant to the topic, be ideologically balanced, offer alternative perspectives, include sources for their arguments, and pose questions for getting more clarity, and foster dialogue, compared to news comments on its Facebook page (Rowe, 2015).

Together with an improvement in the way the spaces for comments are set out, moderation appears to be the most effective measure to help to create a climate which is more conducive to deliberation. After the initial profusion of sections for comments with few mechanisms for their management, in recent years the media have opted to introduce systems to control the content that users publish (Gsell, 2009). Most of them have introduced some kind of registration system, banned anonymous posting, set up filters and, in parallel, introduced systems for moderation (Reader, 2012). In some cases, only subscribers are allowed to comment, for instance on Lemonde.fr. In parallel, various media moved the comments to their Facebook pages, where the 'real name policy' leads to more orderly and respectful participation (Rowe, 2014).

The two main forms of moderation were moderation prior to posting the comments or the moderation done after the fact. Although the former was used to some extent, the latter was initially the more popular type of moderation, involving less intervention, although it involved extra work for the journalists (Reich, 2011). The volume of published comments led the media to outsource moderation, a cost-effective but controversial solution. Firstly, it has proved to be quite ineffective and secondly it runs counter to the philosophy that should govern the momentum of interaction in the media and which would make it possible to take the pulse of the audience (Masip, 2011). 
Without a doubt, users are more willing to participate in a moderated community than in an unmoderated one (Wise; Hamman; Thorson, 2006) and there is an overall link between moderation and the level of civility (Coe; Kenski; Rains, 2014; Ruiz-Caballero et al., 2011). Users are more likely to participate when they know that journalists are moderating (Meyer; Carey, 2014; Ksiazek, 2018) and do so more politely (Stroud et al., 2014; Ksiazek, 2018). Reader often ask for greater involvement of journalists in the spaces of participation and interaction provided by the media [Suau, 2015; Suau; Masip; Ruiz-Caballero (forthcoming)], but with little success (Loke, 2012; Robinson, 2010). Moderation, however, is also viewed as a form of censorship in that comments expressing views that do not align with the predominant voices can be deleted, thus leading to the spiral of silence (Sherrick; Hoewe, 2018).

The introduction of comment moderation systems as described above has not meant the disappearance of incivility, whereas it entails reduction in the number of commentators (Meyer; Carey, 2014). However, they provide an environment in which users who wish to comment feel more comfortable. The mandatory registration and banning of anonymous comments have a direct relationship with the quality of the comments (Ksiazek, 2018) and the respect expressed in them (Santana, 2014), since anonymity has a disinhibiting effect that facilitates forms of expression would not normally occur in an offline environment (Suler, 2004). Anonymous comments are also less likely to motivate a change of opinion by the readers (Haines et al., 2014) and are viewed as less credible (Rains, 2007).

Despite the fact that the move away from anonymity seems to have been strengthened, there are still many who defend the right to anonymity, as a component of the right to privacy (Masip, 2010). They argue that anonymity leads to a greater diversity of views, especially in those contexts in which the use of real names may have repercussions later (Meyer; Carey, 2014) or when dealing with sensitive or personal issues (Wu; Atkin, 2018).

Despite the fact that comments are one of the most popular forms of participation in the media (Newman et al., 2016; Masip et al., 2015; Bergström; Wadbring, 2015), only a minority of the audience post comments on the news on a regular basis, whereas the reading of comments is widespread. Research to date has focused particularly on studying the characteristics and motivations of 'commentators', although several studies have also focused on users who only read the comments (Springer; Engelmann; Pfaffinger, 2015; Diakopoulus; Naaman, 2011).

Lurkers, or those users who do not publish regularly, but read the comments, are present in most online communities (Barnes, 2018), and despite their passive attitude feel part of the community. Barnes (2013) calls them engaged listeners. They may have an emotional reaction to the content, but they do not externalise it, although they may make subsequent use of that content (Hampton, 2016). Springer, Engelmann \& Pfaffinger (2015) take that view that these engaged listeners are also part of the deliberative process, which can take place both through direct participation, by commenting, or in a passive way, reading; or even in less demanding forms such as giving a 'like' (Sorensen, 2016).

The research carried out to date has defined the users of the comments sections of the news fairly clearly. In general, they are active users on social networks, young and mostly men (Bergström, 2008; Stroud; Muddiman; Scacco, 2016). In addition, they show an interest in politics and have a higher level of education (Ziegele et al., 2013; Bergström, 2008), although a recent study in Germany showed users with a low educational level as more likely to post comments (Ziegele et al., 2018). The authors link that change to the aggressive nature of the comments sections, which has led some users to shift their deliberative concerns to more controlled environments (Frankel, 2018).

In addition to the analysis of the socio-demographic characteristics of the commentators, several studies have examined cognitive aspects to explain users' motivation for commenting, usually from the perspective of uses and gratification theory. Springer, Engelmann \& Pfaffinger (2015) identified four dimensions that encompass the main gratification obtained when commenting: cognitive, emotional-entertainment, social-interactive and personal identity.

Users are particularly interested in commenting due to factors related to cognitive dimensions, such as expressing their views or disseminating information (Diakopoulus; Naamer, 2011; Canter, 2013), but they also hope to be able to interact with the authors of the news (Springer; Engelmann; Pfaffinger, 2015). They obtain the greatest satisfaction when this interaction takes place. In line with this, Rojas (2010) also found that users want to share their opinion and correct erroneous information.

The dimension of social integration is also important for users, as they need to feel part of a community, either through commenting or by participating in social networks. Correa, Hinsley \& Gil de Zúñiga (2010) observed that some personal variables such as emotional instability or loneliness were related to a greater use of social media.

Despite the fact that the move away from anonymity seems to have been strengthened, there are still many who defend the right to anonymity, as a component of the right to privacy.

As we have seen, the concept of digital deliberation goes beyond the strict limits of comments having left the newspapers websites and made the leap to the wide avenues of social networks. It also seeks to widen its outlook to take in other forms of deliberation, albeit some of these questionable. We have mentioned lurkers, talked about the engaged listeners and even the likes. Another essential is news sharing, the user's new ability to distribute news on social networks, as well as looking at the new ways they have for obtaining information. 


\section{New news consumption practices}

In recent years, the role of social networks in the consumption of news has gradually gained importance. According to comparative data compiled at an international level, citizens are increasingly using social networks as their primary or secondary source of access to news (Newman et al., 2018). In Spain, for example, $60 \%$ of the population use social networks as their source of news, and $53 \%$ say that they share news on social networks, mainly Facebook and WhatsApp (Newman et al., 2018). By 2011 Olmstead, Michael \& Rosenstiel had already identified the most significant implications of these new behaviour patterns in terms of sharing and consuming news in the public sphere, arguing that, if the search for information on the internet was the most significant change of the previous decade, its role in the new ways in which information is shared, debated and re-disseminated will prove to be the great innovation of the next decade.

Several authors have highlighted the transformative potential and the relevance of users' interactions on social networks with respect to the traditional news cycle, when exchanging or commenting on content related to news or matters of general interest (Nielsen; Schrøder, 2014; Almgren; Olsson, 2015; Newman; Blank, 2012). It is felt that these new dynamics, originating from users who share, recommend or send items of news by means of public or private messages to their contacts on social networks, result in a broadening of the scope of the influence ordinary citizens have on the public sphere (Singer et al., 2011; Papacharissi, 2015b; Klinger; Svensson, 2015), bringing into question the traditional hegemony of the media and journalists as the sole gatekeepers of public interest issues (Suau, 2015).

The concept of news curating, or content curation underpins studies on news sharing, implying a more active and conscious role for the audience in the practice of news sharing (Bruns, 2018). The identification of audiences as potential content curators is closely linked to the euphoria or optimism that arose from the idea of Web 2.0; the social web (Curran et al., 2010). The concept of content curation is closely linked to debates about new audience roles in an environment that fosters new forms of participation (Bruns, 2018, Thorsen, 2013, Bruns; Highfield, 2015). With the rise of social networks, particularly after Barack Obama's victory in the 2008 US presidential elections, the optimistic discourse that generally follows any technological innovation began to revolve around social networks and their transformative potential (Loader; Mercea, 2012; Curran et al., 2010), in what became labelled participatory culture (Deuze; Bruns; Neurberg, 2007, Domingo et al., 2008; Van-Dijck; Nieborg, 2009). The power of participatory culture manifests itself in different areas of society, but does so above all in the media: in a discussion that has switched from user-generated content to user-distributed content (Lietsla; Sirkkuken, 2008; Napoli, 2009), thus focusing the debate on the redistribution of journalistic content. Describing audiences as curators of content (social curators) on social networks implies ascribing an active motivated role to those who share news in 2.0 environments (Bruns, 2018; Villi, 2012): the role of a citizen who selects and interprets the most interesting news content and then shares it on social networks, promoting a dialogue around the theme of shared news.

The concept of a curator is derived from the art world and it is no coincidence that terms like social curator or news curating continue to be used today in reference to the way news is shared on the internet (Bruns, 2018). According to O'Neil (2007), the curator influences how art is experienced, mediating between the audience and the art works. Thanks to the curator's design for an exhibition and creation of a narrative or dialogue between the different pieces, the audience is assisted in their understanding of the overall meaning of the exhibition. The concept of the curator, like so many others, was first appropriated and redefined for the field of marketing, and later, for other areas such as the media (Loader; Mercea, 2012). In its original sense in the art world, it is associated with a professional figure experienced in the selection and interpretation of works of art. A person who is knowledgeable in their field and chooses different pieces to create a discourse that will take the form of an exhibition at a public or private cultural institution. Establishing an analogy between participatory audiences and the figure of the curator involves ascribing significance to the role or motivation of citizens in terms of sharing news. If we call citizens who share, comment on or value news on Facebook, Twitter or WhatsApp social curators or content curators (Clark; Aufderheide, 2009; Villi, 2012), it is clear, therefore, that these practices are motivated and have a direct impact. Recent

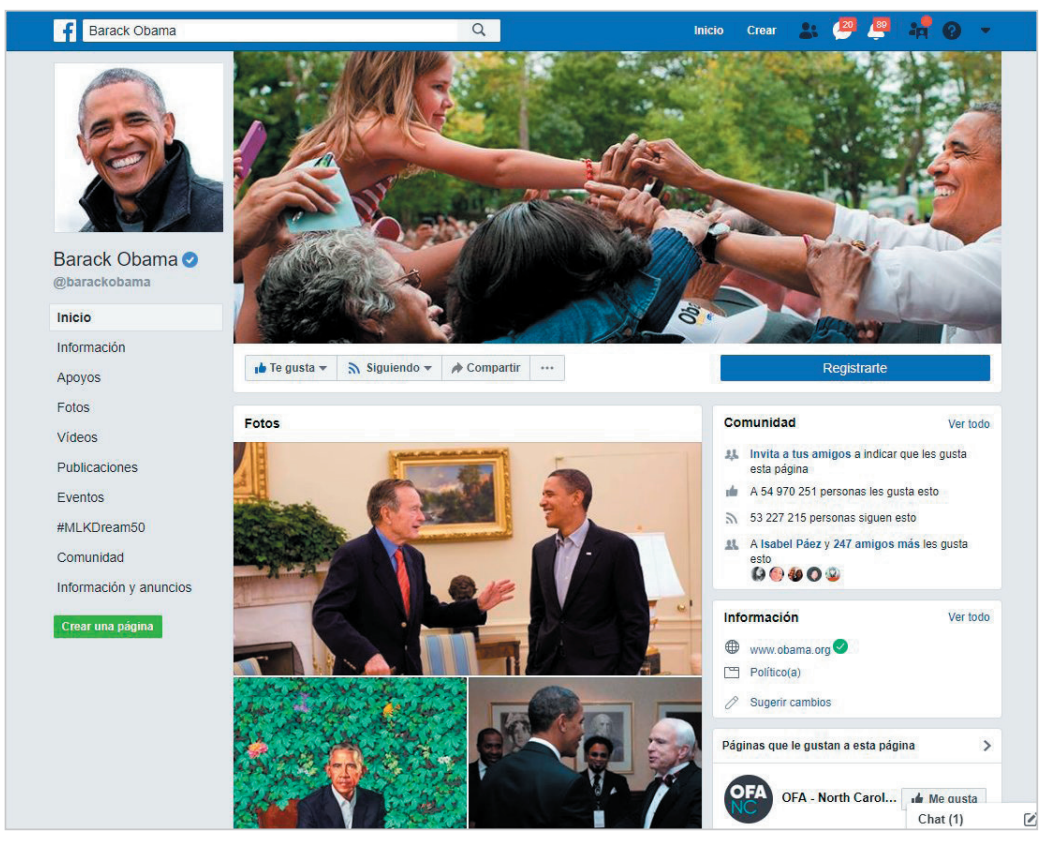

https://www.facebook.com/barackobama 
research demonstrates that sharing content has a marked social exchange nature (Purcell et al., 2010), which seeks to increase ability to influence the community, maintain social cohesion and strengthen social status. Thus the decision to share is neither casual nor random (Goh et al., 2017). For this reason, the term news sharing will be used in this paper to describe the redistribution of content. It is felt that it makes more sense for the term content curation to be associated with the new roles or work practices of journalists, as highlighted by Bakker (2014), or even used in relation to concepts such as reciprocal journalism in regard to maintaining or healing the relationship with audiences (Lewis et al., 2014).

We have adopted Kümple, Karnowski \& Telling's (2015) definition of news sharing which includes all practices that provide a specific group of citizens with access to journalistic content, either by sharing or recommending it on social networks. This definition is useful, since it allows the act of sharing to be separated from the intentionality of the user: news sharing can be occasional or sporadic and can also refer to more conscious, planned activities. Although 'sharing' is a very common practice on social networks (Lampinen, 2015), the concept is limited by referring solely to "news" in a broad sense (Owen, 2018). It is understood therefore that the content shared is of public interest, regardless of its format.

\section{7. 'News sharing': dismantling the 'gatekeeper'}

Evidently the practice of news sharing and commenting was common before the emergence of the internet. From informal conversations to passing the newspaper between friends and family, or cutting out articles of interest, the news has been shared since the invention of the first newspapers or gazettes (Hermida et al., 2012). However, like so many other daily activities, the practice has evolved with the emergence of new technologies, speeding up the processes by which citizens can recommend and redistribute news, first via email or on forums and more recently through WhatsApp, Facebook or Twitter (Kalsnes; Larsson, 2018; Larsson, 2018).

According to Kümpel et al. (2015), the first academic articles about news sharing date from 2005, although it is not until 2010 when a larger number of academic papers on this object of study begin to emerge. Various authors have pointed out the growing number of citizens who practice the re-dissemination or distribution of news content through social networks (Jenkins; Ford; Green, 2013), which in turn has an impact on the number of users who receive news from their own environment (Hermida et al., 2012; Newman; Dutton; Blank, 2012; Purcell et al., 2010; Villi, 2012). Tewksburg \& Rittenberg (2012, p. 158) call this process of citizen involvement in the distribution of relevant content the "democratization of information", because it is closely linked to a change in the consumption of news: from that of a model based on mass audiences to one based more on small connected communities of audiences that share content in different spaces on the internet (Villi, 2012). Choi (2016) identifies two dimensions of the act of news sharing; on the one hand recontextualising and, on the other, endorsing. In other words, sharing not only involves disseminating information, but also re-evaluating it, providing a new framework for its interpretation and an expression of support for the shared content.

Following this argument, Singer (2014) identifies three ways in which users can influence the dissemination and flow of information, turning audiences into "secondary gatekeepers", by:

- providing an evaluation of the contributions of journalists and other users;

- communicating the value or perceived quality of the material; and

- re-diffusing selected content.

While recognizing the fundamental role of social media, Singer acknowledges the use of other less popular tools, such as email or abusive content reporting options, as mechanisms available to users to promote the visibility of news.

All of these 'secondary control' options allow citizens to challenge the old monopoly enjoyed by journalists as the sole guardians of news content, presenting a challenge to the traditional media when determining what is interesting and newsworthy (Shoemaker; Vos, 2009; Singer, 2014; Coddington; Holton, 2014; Vos; Heinderyckx, 2015). Furthermore, when publishing and disseminating content on public issues, it is clear that citizens also exchange opinions and promote debate, in the same way that they do when these issues arise in a gathering of family or friends (Min, 2007). In this sense, several authors (Gil de Zúñiga; Copeland; Bimber, 2013; Dimitrova et al., 2011; Anduiza; Cantijoch; Gallego, 2009) suggest that news sharing, as well as posting comments can be considered an act of political participation or engagement with matters of public interest.

If this is the case, the question arises whether some contents are shared more frequently than others, and following the same reasoning, whether those that are indeed shared more frequently are what Mouffe (2005; 2013) terms "the political". To determine what type of content tends to be shared, read or commented on in greater numbers by users is an issue of immense interest for both the industry and academia (Boczkowski; Mitchelstein, 2012); especially from the point at which website data traffic begins to be considered of economic interest by newsrooms (Olmstead; Mitchell; Rosenstiel, 2011; Singer, 2010; Usher, 2017, Vujnovic et al., 2010). Recent studies have shown that editorial decisions about the positioning of certain articles on the web are affected proportionally by the degree of their diffusion on social networks (Cherubini; Nielsen, 2016, Berger; Milkman, 2009).

Boczkowski, Mitchelstein \& Mora (2018) confirm that news of a political or economic nature tends to be more frequently shared, especially during periods of more intense political activity, such as elections. As was observed during 
the Arab Spring or the protests in Iran in 2009, situations of extreme conflict significantly affect the type of news that is shared (Fahmy, 2012; Zhou et al., 2010). Beyond specific issues, the relevance, surprising or controversial nature of the news affect how viral it goes (Rudat; Buder; Hesse, 2014). Trilling et al. (2016) found that news within a framework of conflict was shared 11\% more on Twitter, and 9\% more on Facebook. Other factors that have similar effects are the human interest (García-Perdomo et al., 2007) or the emotional component of the news (Berger; Milkman, 2010; Kim, 2015), especially that with positive or comforting content (Berger; Milkman, 2010; 2012; Bakshy et al., 2012). Likewise, content from a source considered to be trustworthy, or valued as relevant, also has a greater possibility of being shared (Bandari; Asur; Huberman, 2012; Rudat; Buder; Hesse, 2014).

The social network on which news is shared is also significant. As previously noted, due to the lack of time and financial resources to adequately moderate comment threads, the media turned to a strategy based on incentivising the re-dissemination of content and debate on social networks outside of the media's own spaces (Ihlebaek; Krumsvik, 2015; Villi, 2012). Comparative research carried out into this at an international level shows that Facebook is the main channel on which audiences interact by news sharing, with Twitter being the second (Lichterman, 2016; Nielsen; Schrøder, 2014). Strategies aimed at motivating users to re-disseminate content on any social network are a priority for the media (Krumsvik, 2013), although users who access websites through social networks tend to remain on them for less time than those who access such websites directly (Anderson; Caumont, 2014).

A considerable amount of research has been carried out into what type of content users are more likely to share on social networks. In the first place, the use made of the two major social networks should be differentiated. While Twitter is more frequently used in cases of breaking news and to distribute news to contacts with whom, for the most part, no personal relationship exists (Newman; Dutton; Blank, 2012; Anderson; Caumont, 2014; Masip; Ruiz-Caballero; Suau, 2019), Facebook tends to attract participation that is linked to contacts with whom a connection exists in the offline world: friends, family, acquaintances, etc. (Enjolras et al., 2013; Kormelink; Costera-Meijer, 2015). The Twitter user profile is associated with an older public possessing an elite or specialized component, and it is common to see journalists and politicians especially active on the social network (Newman; Levy, 2014; Engesser; Humpretch, 2015). Hermida et al. (2012) conclude that the role of acquaintances is fundamental on Facebook, since citizens tend to receive (and read) more news if it comes from their friends and family.

\section{Sharing, between selfishness and altruism}

Research into what motivates users to share or debate news on social networks has also received considerable attention from communication studies. In order to define the motivation and attitudes of citizens who share or debate news, it is first worth mentioning the vast diversity of research results presented by this discipline. According to Kalogeropoulos et al. (2017), both the national context and the degree of engagement or connection individuals demonstrate with public affairs are very important when interpreting these different results (Suau, 2015). It is necessary to take such details into account, as otherwise it may appear that some research results in completely contradictory findings. For example, there are a large number of quantitative studies that suggest that the majority of news sharing or debates on social networks are motivated by entertainment or a personal connection with the news item, as opposed to motivations of a political nature or desire to enrich the journalistic process (Baden; Springer, 2014; Larsson, 2012; Paskin, 2010; Heise et al., 2013). However, in their international comparative study Kalogeropoulos et al. (2017) suggest that a positive spiral of reinforcement exists in terms of sharing and debating practices on social networks: with highly motivated or politically active citizens more likely to share news on social networks and to enter into political debates, while those with less involvement or interest in politics or in matters of public interest are less likely to do so. While these results may seem contradictory at first sight, in reality the contextual and personal factors complement each other. Authors such as Valenzuela, Piña \& Ramírez (2017) have pointed to three different factors that influence the practice of sharing and/or debating news: emotion, motivation and psychological connection.

In order to better understand the motivation behind sharing or debating news, it is first necessary to take a moment to consider the characteristics and profile of citizens who adopt this type of participatory practice. First, numerous studies have highlighted the issue of leadership. It is suggested that a large number of citizens who share news or debate more or less regularly on networks tend to identify themselves as having leadership attributes or positions, and display some interest in disseminating their opinion (Hu et al., 2012; Wu et al., 2011; Ma; Lee; Goh, 2013). Also linked to the issue of leadership is the social network user's perception of their own position in relation to public affairs. As pointed out by Kalogeropoulos et al. (2017), those citizens who share most frequently are more connected (Couldry; Livingstone; Markham, 2007) with public affairs: they tend to follow more, and more varied, media, perceiving the sharing of diverse news as positive (Rosengard et al., 2014; Yang; Chang; Chen, 2014). In this sense, the factor of connection with the offline world is very important. Those citizens who maintain strong ties (Gladwell, 2010) off-line tend to share more news, because they perceive that sharing can affect or influence their contacts in a positive way to a greater extent, while also maintaining a positive vision of the effectiveness of sharing their opinions on public forums (Ma; Lee; Goh, 2014). Recent research suggests that, rather than a conscious decision to establish themselves as a leader or reference among their contacts, it is the feeling of being connected and able to influence or disseminate opinions that predisposes citizens to share (Picone; De-Wolf, 2016; Springer; Engelmann; Pfaffinger, 2016). Although this might be the profile of a citizen 
who tends to share the most, contextual factors are also highly relevant. As seen previously, particularly convulsive political contexts (Fahmy, 2012; Zhou et al., 2010), and above all, shocking or outrageous information (Berger, 2011) can result in an increase in the number of citizens sharing news.

Kümpel et al. (2015) classify the motivation for sharing into three main groups: altruistic, social and personal or egoistic. With regard to motivation of a personal or egoistic nature, some research points to entertainment as the main incentive for engaging in participatory practices on social networks (Lee; Ma, 2012; Ma et al., 2012). The emotional rewards of news sharing, with similarities to those of entertainment, have been highlighted by some authors: in which some citizens feel compelled to share those news items that have gone viral in a way that is practically unconscious (Heimbach et al., 2015), while others highlight the desire to share that news with which citizens have a strong emotional attachment (Bright, 2016; Berger; Milkman, 2012; Stieglitz; Dang-Xuan, 2013). Several authors have suggested that some citizens decide to participate as a way to attract attention or gain reputation among their contacts (Boyd; Golder; Lotan, 2010; Berger, 2014). The most relevant altruistic motivation consists of participating in order to maximize the dissemination of information deemed relevant to society (Holton et al., 2014). And finally, those citizens who participate for social reasons are felt to do so out of a desire to socialise or a need to receive social approval (Hanson; Haridakis, 2008; Lee; Ma, 2012).

It should be noted that several studies have indicated that, although relevant in numerical terms, the total number of citizens who participate on social networks remains a minority of overall users (Suau, 2015; Guallar et al., 2016; Masip et al., 2015). Reasons for not participating in either news sharing or commenting, include not wanting to express opinions that might contradict what is believed to be the majority opinion among contacts (Kormelink; Costera-Meijer, 2018). According to Kalsnes \& Larsson (2018), this negative motivation might be numerically significant enough to explain why the majority of citizens do not participate in news sharing or commenting. All this poses the question whether social networks tend to create ideologically homogeneous spaces and it is important, therefore, to consider the possible effects social networks have on the construction of echo chambers, or ideological bubbles, in which citizens tend to only interact with others who hold similar opinions. Phenomena that have attracted much attention in recent years like misinformation and selective exposure are closely related to this issue and are discussed below.

\section{9. 'Echo-chambers' and selective exposure: pluralism threatened}

Since the early years of communication studies the effect of the media on democratic society and, more specifically, its effect on political participation and the configuration of political stances and attitudes, has frequently been the subject of research. Several theories relevant to the traditional media should be outlined before reviewing that related to the internet and new information and communication technologies (Kim; Kim, 2012). In the first place, the theories clustered around the so-called media malaise highlight the negative nature of the effects of the media, especially television, on citizen participation and civic engagement (Bourdieu, 1998; Sartori, 1998). The media's treatment of politics, presenting it as a game or a competition, focusing on political leadership (Mcallister, 2007) is felt to have contributed to apathy and distrust among the electorate (Cappella; Jamieson, 1997). In contrast, other authors argue that the greater availability of information, together with an increase in education in Western countries have had a positive effect on democracy (Dalton, 1996; Inglehart, 1997). Some authors indicate that the consumption of news is positively linked to indicators of political participation and civic engagement (Van-Zoonen, 2005), creating a kind of virtuous circle in which those citizens with more interest in public affairs reinforce their political connection by means of paying constant attention to the media (Norris, 2000).

While different views on the effects of the traditional media exist, there has been little discussion about the health of Western democracies during the years that coincide with the expansion of the internet and, later, that of social networks. Several authors point out that at the end of the 20th Century some indicators of democratic health were concerning (Dahlgren, 2007): demonstrating a decrease in the percentage of electoral participation and affiliation to political parties and a growing distrust in governments (Pharr; Putnam, 2000; Dalton, 1996; Gray; Caul, 2000). This growing discontent towards forms of participation in traditional institutions stood opposite a supposed increase in or tendency towards non-traditional forms of participation or civic involvement (Norris, 2002; Inglehart, 1997; Hall, 2002).

It is in this context that research into the effects of new technologies on democratic Western societies first developed, with the main questions raised during this first stage being similar to those previously asked about the traditional media: do the various types of online participation constitute a new way of attracting citizens to participate in the public sphere? Can social networks and the internet attract political participation or strengthen the civic links of less connected citizens? (Anduiza; Jensen; Jorba, 2012). Given the optimism of the early years of research into new technologies (Quandt, 2018), it is not surprising that the dominant response to these questions was positive (Curran; Fenton; Freedman, 2012). Some authors pointed out that new technologies facilitated greater participation among those citizens who were already connected or active (Best; Krueger, 2005; Jensen, 2006), while others highlighted the ways in which new technologies made it easier to bring more citizens to public life, due to the reduction in costs of information and participation (Min, 2007; Rheingold, 2002; Esser; De-Vreese, 2007). More recently, there have been a large number of studies that have pointed to the positive nature of the internet and social networks in terms of social change, highlighting the role of the internet in social movements (Castells, 2009) and the potential for social networks to increase young people's access 
to issues of public interest (Banaji; Buckingham, 2013). It appeared that Western societies, with citizens still showing an interest in politics but wishing to intervene in it in a far from traditional way, had found on the Internet the ideal space to develop new forms of participation.

This positive optimistic discourse about the effects of new technologies, specifically social networks, on society has been completely lost in recent years. The current dominant discourse about how new technologies are modifying the public sphere, the role of different agents and the transmission and consumption of news, while not pessimistic, is much more moderate. Gone are the optimistic speeches about how the internet was going to change the world, transforming political participation and facilitating more direct intervention in the public sphere. Perhaps the first alarm bells sounded when it was discovered that the same ease of information distribution enjoyed by the ordinary citizen, recalling the joy awakened by the figure of the citizen journalist (Suau, 2015), was available to extremist or terrorist groups, to disseminate their messages and ideology on the internet with no controls (Andersen; Sandberg, 2018). And as for the effects on democracy, debates no longer revolve around whether social networks help attract new citizens to the public sphere, but to what degree they encourage phenomena such as the fragmentation and polarization of societies, as well as the dissemination of disinformation

In political information, the theory of selective exposure argues that citizens tend to choose media that identify with their positions or political ideology

(European Commission, 2018). This debate is developed below; taking as a starting point the revision of one of the theories that has guided research in communication over the last few decades: selective and incidental exposure to news content. How the participatory practices of citizens, especially that of news sharing on social networks, have modified patterns of news consumption is one of the issues that might have facilitated the propagation of misinformation, contributing to the polarization of the public sphere and its fragmentation into small communities of ideologically related individuals.

\section{Bursting the bubble}

The theory of selective exposure was first formulated several decades ago (Lazarsfeld; Berelson; Gaudet, 1948), and has regained a presence in communication studies over recent years as new forms of online participation have permitted citizens to have greater influence over information consumption patterns (Brundidge, 2010). In the field of political information, the theory of selective exposure argues that when citizens make decisions about their media and information consumption, they tend to choose those media that identify with their own political stance or ideology. Even before the advent of the internet, the pernicious effects of selective exposure without limitations were already being discussed by various authors (Galston, 2002; Sunstein, 2001). Due to the tendency citizens have for selective exposure, a media system that fails to promote accidental exposure to contrary points of view leads inexorably to a fragmentation of the public sphere into distinct communities that do not interact, thus contributing to an increased polarization between those of differing political stances (Prior, 2013; 2007; Aalberg; Blekesaune; Elvestad, 2013). In Spain, the tendency citizens show towards selective exposure is well demonstrated. The various studies carried out by Humanes (2016) in relation to the traditional media confirm that the Spanish audience tends to consume those media that they identify as sharing their own ideology or political stance.

As the use of the internet developed and became more generalised (Press; Williams, 2010), debates around selective exposure were revitalised. At first, research pointed to some possible positive consequences of the greater ease of access to news and information on the internet (Newman; Dutton; Blank, 2012; Weber; Loumakis; Bergman, 2003; Tewksbury; Weaver; Maddex, 2001). However, as online environments have developed, especially with the emergence of social networks, views on selective and accidental exposure have changed. Some authors have highlighted the complexity in the current hybrid media system of quantifying each citizen's exposure to information, due to cross-media consumption patterns (Chadwick, 2013; Schrøder, 2013) and the unquestionable fact that the means by which citizens consume news have been completely transformed in recent years (Boulianne, 2015). As stated above, the existing data point to the fact that in Spain around $60 \%$ of citizens consume news and approximately $50 \%$ share information content via social networks (Newman et al., 2018), with the majority of this content comprising links to news from major media outlets received from relatives, friends and acquaintances (Masip et al., 2015). How is selective exposure affected by the new participatory practice of news sharing? The principal subject of debate is whether social networks facilitate selective exposure by creating echo-chambers or filter bubbles where citizens receive only information that is in line with their ideology, or if, on the contrary, the use of social networks facilitates accidental exposure to news, by exposing citizens to un-related ideological content or sources.

Fears generated by the generalization of "social news", or a media environment in which citizens access news mainly via social networks are that news consumption is significantly affected by the configuration of each user's contacts. Based on the fact that our contacts on the most popular social networks are basically our family, friends and acquaintances, some authors suggest that there is a real risk of receiving mostly news that does not question our ideological positions (Bakshy et al., 2015; Groshek; Koc-Michalska, 2017). This creates echo-chambers of political affinity in which only citizens who think in a similar way interact (Dahlgren, 2013), a format that promotes selective exposure without the citizen 
having to make any effort to avoid exposure to different opinions. The algorithms of the social network itself already prioritise control over increasing the visibility of those contacts with whom we interact the most (Pariser, 2011) without taking into account the quality of the news they share (Pasquale, 2015). The 2016 US elections were a trigger for the theory that the creation of ideological bubbles would contribute to the polarization of society and the propagation of false news and disinformation (Sunstein, 2017, Khaldarova; Pantti, 2016), all of which goes some way to explaining the victory of populist candidates like Donald Trump.

However, more recent research offers data that qualifies the most pessimistic views on echo-chambers or ideological bubbles. In the case of Spain, Masip, Suau \& Ruiz-Caballero (2018) point out that accidental exposure exists on social networks: with the Spanish audience not only receiving information contrary to their points of view, but some also sharing it. Although it is true that there is a tendency towards greater ideological affinity between contacts on social networks, on two of the main social networks there exists an element of discordant voices, Facebook and WhatsApp (Suau, 2015). Studies in other countries back up these results, indicating that accidental exposure is favoured and exposure to unrelated points of view is superior to that initially thought to be the case, reducing the importance of selective exposure on social networks (Bakshy et al., 2012; Barberá et al., 2015) as well as on other platforms such as Google News (Haim; Graefe; Brosius, 2018). Although on a general level it seems that there is no relation between the use of social networks and an increase in polarization (Boxell et al., 2017), various studies demonstrate differences between groups of citizens. With Dubois and Blank (2018) establishing that those citizens most interested in politics and those who pay greater attention to the media are more likely to avoid ideological bubbles.

Although the existence of ideological bubbles is a reality, there does not seem to be any one factor that determines the inevitability of being trapped in one. Thus it seems that, on social networks as in the analogical world, the most significant factor in their emergence is the way citizens behave. As Bechman \& Nielbo (2018) argue, regardless of other factors such as gender, age or level of education, the greater number of contacts and variety of pages followed, the lower the likelihood of selective exposure. Having a greater number of contacts on social networks also facilitates accidental exposure (Fletcher; Nielsen, 2018).

It should also be noted that accidental exposure, although necessary, is generally associated with low levels of political awareness. As highlighted by Gil de Zúñiga et al. (2017), those citizens whose main source of news comes from accidental exposure on social networks, tend to display lower levels of awareness and understanding of public affairs, compared to those who consume media directly. In turn, those citizens who mostly consume accidental news are also more likely to believe in fake news and other types of misinformation, or assume it to be correct (European Commission, 2018). It is therefore still too early to determine how and at what level, online disinformation affects the political stance of citizens (Alcott; Gentskow, 2017) or if, as is feared, it contributes to polarization (Flaxman et al., 2016; Peterson et al., 2018). Recent electoral processes in Europe, as well as in the United States and Brazil, have brought media issues such as the dissemination of disinformation via social networks and WhatsApp to the fore. In the coming years, research in the field of communication studies will be tasked with investigating these phenomena in detail in order to clarify the specific effects of exposure to misinformation, as well as the real level at which the re-dissemination of these contents affects political at-
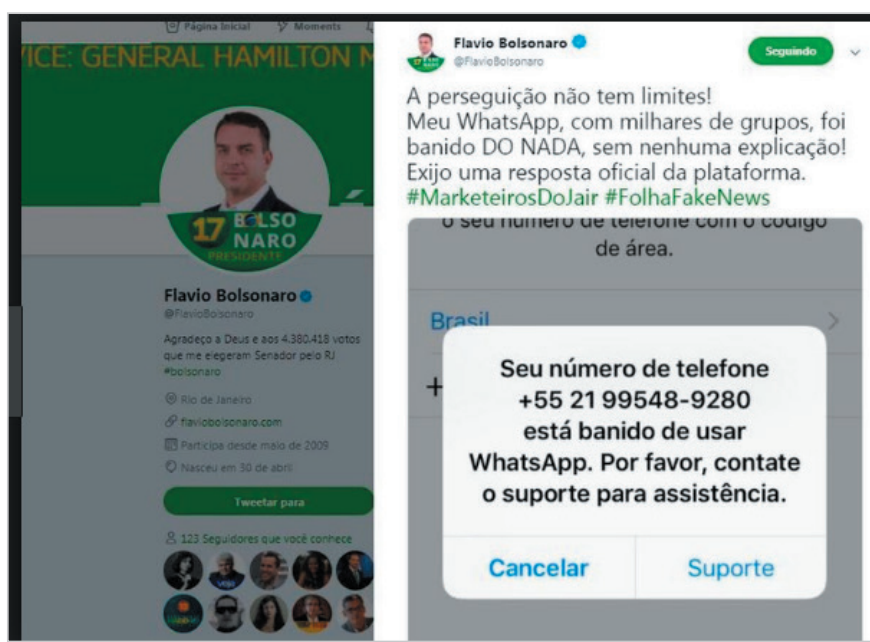

Whatsapp de Flavio Bolsonaro

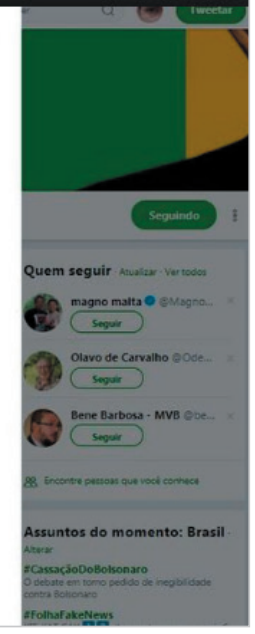

titudes and stances.

\section{Final considerations, concerning Dewey}

Dewey (1946) reminds us of the link, beyond the merely verbal, between the words common, community and communication. Human beings live in community by virtue of what they have in common, and communication is the way by which they come to have these things in common. Among such common elements, the pragmatic philosopher emphasized knowledge, making a common intelligence possible. Communication should ensure participation in this common intelligence, the epistemological dimension reclaimed by Habermas (2006). Almost a century ago, Dewey reflected on the concept of public opinion and considered that the problem was not that the public, that is, a large body of people who have a common interest in the consequences of social transactions, did not exist. The problem, he said, was that there was too much public: that it was too diffuse, scattered and intricate in its composition. And he added, as if twee- 
ting: how can a public be organized (...) when it literally will not stay in one place? Dewey reflected on this in a public sphere that was already a faded image of Habermas' concept. However as Dewey stated, the essential need, both then and now, is the same:

"the improvement of the methods and conditions of debate, discussion and persuasion".

This, he concluded, "is the problem of the public". And we add: this is the problem of the public sphere, of public opinion and of democracy.

\section{Note}

1. Here we are referring to conversations such as the group of comments posted on a news story, either on media or platforms such as Facebook or Twitter.

\section{References}

Aalberg, Toril; Blekesaune, Arild; Elvestad, Eiri (2013). "Media choice and informed democracy: Toward increasing news consumption gaps in Europe". The international journal of press/politics, v. 18, n. 3, pp. 281-303.

https://doi.org/10.1177/1940161213485990

Aalberg, Toril; Van-Aelst, Peter; Curran, James (2010). "Media systems and the political information environment: A cross-national comparison". The international journal of press/politics, v. 15, n. 3, pp. 255-271.

https://doi.org/10.1177/1940161210367422

Allcott, Hunt; Gentzkow, Matthew (2017). "Social media and fake news in the 2016 election". Journal of economic perspectives, v. 31, n. 2, pp. 211-236.

https://doi.org/10.1257/jep.31.2.211

Almgren, Susanne M.; Olsson, Tobias (2015). “Let's get them involved... to some extent: Analyzing online news participation". Social media + society, v. 1, n. 2, pp. 1-11.

https://doi.org/10.1177/2056305115621934

Andersen, Jan-Christoffer; Sandberg, Sveinung (2018). “Islamic State propaganda: Between social movement framing and subcultural provocation". Terrorism and political violence, Online first.

https://doi.org/10.1080/09546553.2018.1484356

Anderson, Ashley A.; Brossard, Dominique E.; Scheufele, Dietram A. (2012). "Online talk: how exposure to disagreement in online comments affects beliefs in the promise of contro- versial science". In: L. J. Phillips; A. Carvalho; J. Doyle (eds.). Citizen voices: Performing public participation in science and environment communication. Bristol: Intellect, pp. 119-136. ISBN: 9781841506210

Anderson, Ashley A.; Brossard, Dominique; Scheufele, Dietram A.; Xenos, Michael A.; Ladwig, Peter (2014). "The 'Nasty effect:' Online incivility and risk perceptions of emerging technologies". Journal of computer-mediated communication, v. 19, n. 3, pp. 373-387.

https://doi.org/10.1111/jcc4.12009

Anderson, Monica; Caumont, Andrea (2014). How social media is reshaping news. Pew Research Center. http://www.pewresearch.org/fact-tank/2014/09/24/how-social-media-is-reshaping-news

Anduiza, Eva; Cantijoch, Marta; Gallego, Aina (2009). "Political participation and the Internet". Information, communication and society, v. 12, n. 6, pp. 860-878.

https://doi.org/10.1080/13691180802282720

Anduiza, Eva; Cristancho, Camilo; Sabucedo, José M. (2014). “Mobilization through online social networks: the political protest of the indignados in Spain". Information, communication and society, v. 17, n. 6, pp. 750-764.

https://doi.org/10.1080/1369118X.2013.808360

Anduiza, Eva; Jensen, Michael; Jorba, Laia (2012). Digital media and political engagement around the world: A comparative analysis. Cambridge: Cambridge University Press. ISBN: 9781107668492

Baden, Christian; Springer, Nina (2014). “Com(ple)menting the news on the financial crisis: The contribution of news users' commentary to the diversity of viewpoints in the public debate". European journal of communication, v. 29, n. 5, pp. 529-548.

https://doi.org/10.1177/0267323114538724

Bakker, Piet; Pantti, Mervi (2009). "Beyond news: user-generated content on Dutch media websites". In: Future of journalism conference. Cardiff, Wales, 9-10 September.

https://www.researchgate.net/publication/229016844_Beyond_News_User-generated_content_on_Dutch_media_ websites 
Bakker, Piet (2014). "Mr. Gates returns: Curation, community management and other new roles for journalists". Journalism studies, v. 15, n. 5, pp. 596-606.

https://doi.org/10.1080/1461670X.2014.901783

Bakshy, Eytan; Rosenn, Itamar; Marlow, Cameron; Adamic, Lada-Ariana (2012). "The role of social networks in information diffusion". In: Procs of the $21^{\text {st }}$ intl conf on world wide web.

https://dl.acm.org/citation.cfm?id=2187907

Bakshy, Eytan; Messing, Solomon; Adamic, Lada-Ariana (2015). "Exposure to ideologically diverse news and opinion on Facebook". Science, v. 348, n. 6239, pp. 1130-1132.

https://doi.org/10.1126/science.aaa1160

Banaji, Shakuntala; Buckingham, David (2013). The civic web: Young people, the internet, and civic participation. Cambridge, The MIT Press. ISBN: 9780262019644

Bandari, Roja; Asur, Sitaram; Huberman, Bernardo A. (2012). "The pulse of news in social media: Forecasting popularity". In: Procs of the Sixth intl AAAl conf on weblogs and social media.

https://www.aaai.org/ocs/index.php/ICWSM/ICWSM12/paper/viewFile/4646/4963

Barber, Benjamin R. (1984). Strong democracy: Participatory politics for a new age. Berkeley: University of California Press. ISBN: 9780520056167

Barberá, Pablo; Jost, John T.; Nagler, Jonathan; Tucker, Joshua A.; Bonneau, Richard (2015). "Tweeting from left to right: Is online political communication more than an echo chamber?". Psychological science, v. 26, n. 10, pp. $1531-1542$. https://doi.org/10.1177/0956797615594620

Barnes, Renee (2018). Uncovering online. Commenting online: Trolls, fanboys and lurkers. Cham, SW: Palgrave MacmiIlan. ISBN: 9783319702346

Barnes, Renee (2013). “The 'ecology of participation'. A study of audience engagement on alternative journalism websites". Digital journalism, v. 2, n. 4, pp. 542-557.

https://doi.org/10.1080/21670811.2013.859863

Batorski, Dominik; Grzywińska, Ilona (2018). "Three dimensions of the public sphere on Facebook". Information, communication and society, v. 21, n. 3, pp. 356-374.

https://doi.org/10.1080/1369118X.2017.1281329

Bauman, Zygmund (2000). Liquid modernity. Cambridge: Polity Press. ISBN: 9780745624105

Bauman, Zygmund (2005). Liquid life. Cambridge: Polity Press. ISBN: 9780745635156

Bechmann, Anja; Nielbo, Kristoffer L. (2018). “Are we exposed to the same 'news' in the news feed?: An empirical analysis of filter bubbles as information similarity for Danish Facebook users". Digital journalism, v. 6, n. 8, pp. 990-1002. https://doi.org/10.1080/21670811.2018.1510741

Beck, Ulrich; Willms, Johannes (2004). Conversations with Ulrich Beck. Cambridge: Polity Press. ISBN: 9780745628233

Benkler, Yochai (2006). The wealth of networks: How social production transforms markets and freedom. New Haven: Yale UP. ISBN: 9780300110562

http://www.benkler.org/Benkler_Wealth_Of_Networks.pdf

Benkler, Yochai; Roberts, Hal; Faris, Robert; Solow-Niederman, Alicia; Etling, Bruce (2015). "Social mobilization and the networked public sphere: Mapping the SOPA-PIPA debate". Political communication, v. 32, n. 4, pp. 594-624.

https://doi.org/10.1080/10584609.2014.986349

Bennett, W. Lance (2008). Civic life online: Learning how digital media can engage youth. Cambridge MA: MIT Press. ISBN: 9780262026345

Bennett, W. Lance; lyengar, Shanto (2008). "A new era of minimal effects? The changing foundations of political communication". Journal of communication, v. 58, pp. 707-731.

https://doi.org/10.1111/j.1460-2466.2008.00410.x

Bennett, W. Lance; Segerberg, Alexandra (2013). The logic of connective action: Digital media and the personalization of contentious politics. Cambridge University Press. ISBN: 9781107642720

Berger, Jonah; Milkman, Katherine L. (2012). "What makes online content viral?” Journal of marketing research, v. 49, n. 2, pp. 192-205.

https://doi.org/10.1509/jmr.10.0353 
Bergström, Annika (2008). "The reluctant audience: Online participation in the Swedish journalistic context". Westminster papers in communication and culture, v. 5, n. 2, pp. 60-79.

http://citeseerx.ist.psu.edu/viewdoc/download?doi=10.1.1.475.3657\&rep=rep1\&type=pdf

Bergström, Annika; Wadbring, Ingela (2015). "Beneficial yet crappy: Journalists and audiences on obstacles and opportunities in reader comments". European journal of communication, v. 30, n. 2, pp. 137-151.

https://doi.org/10.1177/0267323114559378

Best, Samuel J.; Krueger, Brian S. (2005). "Analyzing the representativeness of internet political participation". Political behavior, v. 27, n. 2, pp. 183-216.

https://doi.org/10.1007/s11109-005-3242-y

Boczkowski, Pablo J.; Mitchelstein, Eugenia (2012). "How users take advantage of different forms of interactivity on online news sites: Clicking, e-mailing, and commenting". Human communication research, v. 38, n. 1, pp. 1-22. https://doi.org/10.1111/j.1468-2958.2011.01418.x

Boczkowski, Pablo J.; Mitchelstein, Eugenia; Matassi, Mora (2018). "News comes across when I'm in a moment of leisure: Understanding the practices of incidental news consumption on social media". New media and society, v. 20, n. 10, pp. 3523-3539.

https://doi.org/10.1177/1461444817750396

Borger, Merel; Van-Hoof, Anita; Costera-Meijer, Irene; Sanders, José (2013). “Constructing participatory journalism as a scholarly object: A genealogical analysis". Digital journalism, v. 1, n. 1, pp. 117-134.

https://doi.org/10.1080/21670811.2012.740267

Boulianne, Shelley (2015). "Social media use and participation: A meta-analysis of current research". Information, communication and society, v. 18, n. 5, pp. 524-538.

https://doi.org/10.1080/1369118X.2015.1008542

Bourdieu, Pierre (1998). On television and journalism. London: Pluto Press. ISBN: 9780745313337

Boxell, Levi; Gentzkow, Matthew; Shapiro, Jesse M. (2017). “Is the Internet causing political polarization? Evidence from demographics". NBER Working paper No. W23258.

https://www.nber.org/papers/w23258.pdf

Boyd, Danah (2007). "Why youth (heart) social network sites: The role of networked publics in teenage social life". In: D. Buckingham (ed.). Macarthur Foundation series on digital learning - Youth, identity, and digital media. Cambridge, MA: MIT Press, pp. 1-26. ISBN: 9780262524834

Boyd, Danah; Ellison, Nicole B. (2007). "Social network sites: Definition, history, and scholarship". Journal of computer-mediated communication, v. 13, n. 1, pp. 210-230.

https://doi.org/10.1111/j.1083-6101.2007.00393.x

Boyd, Danah; Golder, Scott; Lotan, Gilad (2010). "Tweet, tweet, retweet: conversational aspects of retweeting on Twitter". In: HICSS-43. IEEE: Kauai, HI, January 6.

https://www.danah.org/papers/TweetTweetRetweet.pdf

Brenne, Sarah (2016). "Political discussion on social media and the public sphere". Sociology and anthropology, v. 4 , n. 4, pp. 270-275.

https://doi.org/10.13189/sa.2016.040410

Bright, Jonathan (2016). "The social news gap: How news reading and news sharing diverge". Journal of communication, v. 66, n. 3, pp. 343-65.

https://doi.org/10.1111/jcom.12232

Broersma, Marcel; Graham, Todd (2013). "Twitter as a news source”. Journalism practice, v. 7, n. 4, pp. 446-464. https://doi.org/10.1080/17512786.2013.802481

https://www.rug.nl/research/portal/files/12824342/Broersma_and_Graham_2013.pdf

Brooks, Deborah-Jordan; Geer, John G. (2007). "Beyond negativity: The effects of incivility on the electorate". American journal of political science, v. 51, n. 1, pp. 1-16.

https://doi.org/10.1111/j.1540-5907.2007.00233.x

Brundidge, Jennifer (2010). “Encountering 'difference' in the contemporary public sphere: The contribution of the internet to the heterogeneity of political discussion networks”. Journal of communication, v. 60, n. 4, pp. 680-700.

https://doi.org/10.1111/j.1460-2466.2010.01509.x

Bruns, Axel; Highfield, Tim (2016). "Is Habermas on Twitter? Social media and de public Sphere". In: Bruns, Axel et al. (eds.). The Routledge companion to social media and politics. New York: Routledge, pp. 56-73. ISBN: 9781138300934 https://eprints.qut.edu.au/91810 
Bruns, Axel; Highfield, Tim (2015). "From news blogs to news on Twitter: Gatewatching and collaborative news curation". In: Coleman, Stephen; Freelon, Deen. Handbook of digital politics. Cheltenham: Edward Elgar Publishing, pp. 325339. ISBN: 9781786435637

https://eprints.qut.edu.au/84995

Bruns, Axel (2008a). "Life beyond the public sphere: Towards a networked model for political deliberation". Information polity, v. 13, n. 1-2, pp. 65-79.

https://dl.acm.org/citation.cfm?id=1412691

Bruns, Axel (2008b). Blogs, Wikipedia, Second Life, and beyond: From production to produsage. New York: Peter Lang. ISBN: 9780820488660

Bruns, Axel (2018). Gatewatching and news curation: Journalism, social media, and the public sphere. New York: Peter Lang. ISBN: 9781433133206

https://goo.gl/k8hqPN

Bruns, Axel; Highfield, Tim, Burgess; Jean (2013). "The Arab Spring and social media audiences: English and Arabic Twitter users and their networks". American behavioral scientist, v. 57, n. 7, pp. 871-898.

https://doi.org/10.1177/0002764213479374

Butsch, Richard (2008). The citizen audience. crowds, publics, and individuals. London: Routledge. ISBN: 9780415977890

Calhoun, Craig (1992). "Introduction: Habermas and the public sphere". In: Calhoun, C. (ed.). Habermas and the public sphere. Cambridge: The MIT Press, pp. 1-44. ISBN: 9780262531146

Camaj, Lindita; Santana, Arthur D. (2015). "Political deliberation on Facebook during electoral campaigns: Exploring the relevance of moderator's technical role and political ideology". Journal of information technology and politics, v. 12, v. 4, pp. 325-341.

https://doi.org/10.1080/19331681.2015.1100224

Canter, Lily (2013). "The misconception of online comment threads: Content and control on local newspaper websites". Journalism practice, v. 7, n. 5, pp. 604-619.

https://doi.org/10.1080/17512786.2012.740172

Cappella, Joseph N.; Jamieson, Kathleen-Hall (1997). Spiral of cynicism: The press and the public good. New York: Oxford University Press. ISBN: 9780195090642

Castells, Manuel (2009). Communication power. Oxford: Oxford University Press. ISBN: 9780199595693

Chadwick, Andrew (2013). The hybrid media system: Politics and power. Oxford, England: Oxford University Press. ISBN: 9780199759477

Chen, Gina-Masullo; Lu, Shuning (2017). "Online political discourse: Exploring differences in effects of civil and uncivil disagreement in news website comments". Journal of broadcasting \& electronic media, v. 61, n. 1, pp. 108-125.

https://doi.org/10.1080/08838151.2016.1273922

Cherubini, Federica; Nielsen, Rasmus-Kleis (2016). Editorial analytics: How news media are developing and using audience data and metrics. Oxford: Reuters Institute for the Study of Journalism.

https://reutersinstitute.politics.ox.ac.uk/our-research/editorial-analytics-how-news-media-are-developing-and-usingaudience-data-and-metrics

Choi, Jihyang (2016). "News internalizing and externalizing: The dimensions of news sharing on online social networking sites sharing news on social networking sites". Journalism \& mass communication quarterly, v. 93, n. 4, pp. 816-835.

https://doi.org/10.1177/1077699016628812

Clark, Jessica; Aufderheide, Patricia (2009). Public media 2.0: Dynamic, engaged publics. Center for Media and Social Media.

http://cmsimpact.org/sites/default/files/documents/pages/publicmedia2.0.pdf

Coddington, Mark; Holton, Avery E. (2014). "When the gates swing open: Examining network gatekeeping in a social media setting". Mass communication and society, v. 17, n. 2, pp. 236-257.

https://doi.org/10.1080/15205436.2013.779717

Coe, Kevin; Kenski, Kate; Rains, Stephen A. (2014). “Online and uncivil? Patterns and determinants of incivility in newspaper website comments". Journal of communication, v. 64, n. 4, pp. 658-679.

https://doi.org/10.1111/jcom.12104

Cooke, Nicole A. (2018). Fake news and alternative facts: Information literacy in a post-truth era. Chicago: ALA Editions. ISBN: 9780838916360 
Correa, Teresa; Hinsley, Amber-Willard; Gil de Zúñiga, Homero (2010). "Who interacts on the web?: The intersection of users' personality and social media use". Computers in human behavior, v. 26, n. 2, pp. 247-253.

https://doi.org/10.1016/j.chb.2009.09.003

Couldry, Nick (2003). Media rituals: A critical approach. London: Routledge. ISBN: 9781134490172

Couldry, Nick; Livingstone, Sonia; Markham, Tim (2007). Media consumption and public engagement. New York: Palgrave Macmillan. ISBN: 9780230800823

Cunningham, Stuart (2001). "Popular media as public 'sphericules' for diasporic communities". International journal of cultural studies, v. 4, n. 2, pp. 131-147.

https://doi.org/10.1177/136787790100400201

Curran, James (2011a). Media and democracy. Communication and society. London, England: Routledge. ISBN: 9780 415317078

Curran, James (2011b). Media and society. London, England: Bloomsbury. ISBN: 9780340984451

Curran, James; Fenton, Natalie; Freedman, Des (2012). Misunderstanding the Internet. New York: Routledge. ISBN: 978 0415579582

https://courses.helsinki.fi/sites/default/files/course-material/4511752/CURRAN\%20ET\%20AL_Misunderstanding\%20 the\%20internet.pdf

Dahlberg, Lincoln (2005). "The Habermasian public sphere: A specification of the idealized conditions of democratic communication". Studies in social and political thought, n. 10, pp. 2-18.

https://www.sussex.ac.uk/webteam/gateway/file.php?name=10-1a.pdf\&site=412

Dahlberg, Lincoln (2011). “Re-constructing digital democracy: An outline of four 'positions'”. New media \& society, v. 13, n. 6, pp. 855-872.

https://doi.org/10.1177/1461444810389569

Dahlgren, Peter (2000a). "The Internet and the democratization of civic culture". Political communication, n. 17, pp. 335-340.

https://doi.org/10.1080/10584600050178933

Dahlgren, Peter (2000b). "Media, citizens and civic culture”. In: M. Gurevitch; J. Curran (eds.). Mass media and society, $3^{\text {rd }}$ ed. London: Edward Arnold, pp. 310-328. ISBN: 9780340884997

Dahlgren, Peter (2003). "Reconfiguring civic culture in the new media milieu". In: J. Comer; D. Pels (eds.). Media and political style: Essays on representation and civic culture. London: Sage, pp. 151-170.

Dahlgren, Peter (2005). "The Internet, public spheres, and political communication: Dispersion and deliberation". Political communication, n. 22, pp. 147-162.

https://doi.org/10.1080/10584600590933160

Dahlgren, Peter (2007). "Youth, civic engagement and learning via new media". In: Peter Dahlgren (ed.). Young citizens and new media: Learning for democratic participation. New York: Routledge, pp. 1-18. ISBN: 9780415395991

Dahlgren, Peter (2009). Media and political engagement: Citizens, communication, and democracy. Cambridge: Cambridge UP. ISBN: 9780521527897

Dahlgren, Peter (2013). The political web. New York, NY: Palgrave Macmillan. ISBN: 9781137326379

Dalton, Russell J. (1996). Citizen politics: Public opinion and political parties in advanced Western democracies. Chatham: Sage.

Davenport, Thomas; Beck, John C. (2001). The attention economy: Understanding the new economy of business. Boston, MA: Harvard Business Review Press. ISBN: 9781578518715

Del Vicario, Michela; Bessi, Alessandro; Zollo, Fabiana; Petroni, Fabio; Scala, Antonio; Caldarelli, Guido; Stanley, H. Eugene; Quattrociocchi, Walter (2016). "The spreading of misinformation online". Proceedings of the National Academy of Sciences, v. 113, n. 3, pp. 554-559.

https://doi.org/10.1073/pnas.1517441113

Deuze, Mark (2001). "Understanding the impact of the Internet. On new media professionalism, mindsets and buzzwords". Ejournalism.

https://www.researchgate.net/publication/254750080_Understanding_the_impact_of_the_Internet_On_new_media_ professionalism_mindsets_and_buzzwords

Deuze, Mark; Bruns, Axel; Neuberger, Christoph (2007). "Preparing for an age of participatory news". Journalism practice, v. 1, n. 3, pp. 322-338.

https://doi.org/10.1080/17512780701504864 
Dewey, John (1946). The public and its problems. An essay in political inquiry. Chicago: Gateway Books. ISBN: 9780 804011662

Diamond, Larry-Jay; Plattner, Marc F. (2012). Liberation technology: Social media and the struggle for democracy. Baltimore, MD: Johns Hopkins University Press. ISBN: 9781421405681

https://hci.stanford.edu/courses/cs047n/readings/diamond-libtech.pdf

Dimitrova, Daniela V.; Shehata, Adam; Strömbäck, Jesper; Nord, Lars W. (2011). "The effects of digital media on political knowledge and participation in election campaigns: Evidence from panel data". Communication research, v. $41, \mathrm{n}$. 1, pp. 95-118.

https://doi.org/10.1177/0093650211426004

Domingo, David; Quandt, Thorsten; Heinonen, Ari; Paulussen, Steve; Singer, Jane B.; Vujnovic, Marina (2008). "Participatory journalism practices in the media and beyond. An international comparative study of initiatives in online newspapers". Journalism practice, v. 2, n. 3, pp. 326-342.

https://doi.org/10.1080/17512780802281065

Dubois, Elizabeth; Blank, Grant (2018). "The echo chamber is overstated: The moderating effect of political interest in diverse media". Information communication and society, v. 21, n. 5, pp. 729-745.

https://doi.org/10.1080/1369118X.2018.1428656

Dvir-Gvirsman, Shira (2017). “Media audience homophily: Partisan websites, audience identity and polarization processes". New media \& society, v. 19, n. 7, pp. 1072-1091.

https://doi.org/10.1177/1461444815625945

Edstrom, Maria (2016) "The trolls disappear in the light: Swedish experiences of mediated sexualised hate speech in the aftermath of Behring Breivik". International journal for crime, justice and social democracy, v. 5, n. 2, pp. 96-106.

https://doi.org/10.5204/ijcjsd.v5i2.314

Eltantawy, Nahed; Wiest, Julie B. (2011). "The Arab Spring| social media in the Egyptian Revolution: Reconsidering resource mobilization theory". International journal of communication, v. 5, pp. 1207-1224.

http://ijoc.org/index.php/ijoc/article/view/1242

Engesser, Sven; Humprecht, Edda (2015). “Frequency or skillfulness”. Journalism studies, v. 16, n. 4, pp. 513-529. https://doi.org/10.1080/1461670X.2014.939849

Enjolras, Bernard; Steen-Johnsen, Kari; Wollebaek, Dag (2013). “Social media and mobilization to offline demonstrations: Transcending participatory divides?". New media \& society, v. 15, n. 6, pp. 890-908.

https://doi.org/10.1177/1461444812462844

Esser, Frank; De-Vreese, Claes H. (2007). “Comparing young voters' political engagement in the United States and Europe". American behavioral scientist, v. 50, n. 9, pp. 1195-1213.

https://doi.org/10.1177/0002764207299364

European Commission (2018). Final report of the High Level Expert Group on fake news and online disinformation. A multi-dimensional approach to disinformation.

https://ec.europa.eu/digital-single-market/en/news/final-report-high-level-expert-group-fake-news-and-onlinedisinformation

Fahmy, Nagwa-Abdel-Salam (2012). "News diffusion and facilitation of conversation" Journal of Middle East Media, v. 8, n. 1, pp. 1-21.

http://connection.ebscohost.com/c/articles/90596188/news-diffusion-facilitation-conversation

Fisher, Caroline (2017). "Bypassing the news media: Politicians and public regaining control”. Reuters Institute Digital News Report, Ireland, pp. 98-100.

Fisher, Caroline; Culloty, Eileen; Lee, Jee-Young; Park, Sora (2019). "Regaining Control Citizens who follow politicians on social media and their perceptions of journalism". Digital journalism, Online first.

https://doi.org/10.1080/21670811.2018.1519375

Flaxman, Seth; Goel, Sharad; Rao, Justin M. (2016). "Filter bubbles, echo chambers, and online news consumption". Public opinion quarterly, v. 80, n. S1, pp. 298-320.

https://doi.org/10.1093/poq/nfw006

Fletcher, Richard; Nielsen, Rasmus Kleis (2018). "Are people incidentally exposed to news on social media? A comparative analysis". New media and society, v. 20, n. 7, pp. 2450-2468.

https://doi.org/10.1177/1461444817724170 
Foucault, Michel (1977). Discipline \& punish: The birth of the prison. New York: Random House. ISBN: 9780679752554 Frankel, Mark (2018). The promises and pitfalls of reporting within chat apps and other semi-open platforms: A journalist's guide.

http://www.niemanlab.org/2018/07/a-journalists-guide-to-the-promises-and-pitfalls-of-reporting-within-open-andclosed-and-semi-open-platforms

Fraser, Nancy (1992). "Rethinking the public sphere: A contribution to the critique of actually existing democracy". In: C. Calhoun (ed.). Habermas and the public sphere. Cambridge MA: MIT Press, pp. 109-142. ISBN: 9780262531146

Galston, William (2002). "The impact of the Internet on civic life: An early assessment". In: E. Kamarck; J. Nye (eds.). Governance.com: Democracy in the information age. Washington, DC: Brookings, pp. 40-58. ISBN: 9780815702177

Galston, William (2003). "If political fragmentation is the problem, is the Intemet the solution?". In: D. M. Anderson; M. Cornfield (eds.). The civic web: Online politics and democratic values. Lanham, MD: Rowman; Littlefield, pp. 35-44. ISBN: 9780742501942

García-Perdomo, Víctor; Salaverría, Ramón; Kilgo, Danielle K.; Harlow, Summer (2018). "To share or not to share: The influence of news values and topics on popular social media content in the United States, Brazil, and Argentina". Journalism studies, v. 19, n. 8, pp. 1180-1201.

https://doi.org/10.1080/1461670X.2016.1265896

Garrett, R. Kelly (2009). "Politically motivated reinforcement seeking: Reframing the selective exposure debate". Journal of communication, v. 59, n. 4, pp. 676-699.

https://doi.org/10.1111/j.1460-2466.2009.01452.x

Giddens, Anthony (1991). Modernity and self-identity: self and society in the late modern age. Cambridge: Polity Press. ISBN: 9780804719445

Gil de Zúñiga, Homero; Copeland, Lauren; Bimber, Bruce (2013). “Political consumerism: Civic engagement and the social media connection". New media \& society, v. 16, n. 3, pp. 488-506.

https://doi.org/10.1177/1461444813487960

Gil de Zúñiga, Homero; Weeks, Brian; Ardèvol-Abreu, Alberto (2017). "Effects of the news-finds-me perception in communication: Social media use implications for news seeking and learning about politics". Journal of computer-mediated communication, v. 22, n. 3, pp. 105-123.

https://doi.org/10.1111/jcc4.12185

https://goo.gl/Tqss4Q

Gillmor, Dan (2004). We the media: Grassroots journalism, by the people, for the people. Sebastopol: O'Reilly. https://goo.gl/HGo79e

Gitlin, Todd (1998). "Public sphere or public sphericules?". In: T. Liebes and J. Curran (eds.). Media, ritual and identity. London: Routledge, pp. 175-202. ISBN: 9780415159913

Gladwell, Malcolm (2010). "Small change". The New Yorker. October, 4.

https://www.newyorker.com/magazine/2010/10/04/small-change-malcolm-gladwell

Goh, Debbie; Ling, Richard; Huang, Liuyu; Liew, Doris (2017). “News sharing as reciprocal exchanges in social cohesion maintenance". Information communication and society. https://doi.org/10.1080/1369118X.2017.1406973

Goldhaber, Michael H. (1997). "The attention economy and the Net". First Monday, v. 2, n. 4. https://firstmonday.org/article/view/519/440

Gonçalves, João (2018). "Aggression in news comments: How context and article topic shape user-generated content". Journal of applied communication research, v. 46, n. 5, pp. 604-620.

https://doi.org/10.1080/00909882.2018.1529419

Gray, Mark; Caul, Miki (2000). “Declining voter turnout in advanced industrial democracies, 1950 to 1997: The effects of declining group mobilization". Comparative political studies, v. 33, n. 9, pp. 1091-1122.

https://doi.org/10.1177/0010414000033009001

Groshek, Jacob; Koc-Michalska, Karolina (2017). "Helping populism win? Social media use, filter bubbles, and support for populist presidential candidates in the 2016 US election campaign". Information, communication and society, v. 20, n. 9, pp. 1389-1407.

https://doi.org/10.1080/1369118X.2017.1329334

Gsell, Lindsay (2009). "Comments anonymous: Newspaper web sites wrestle with offensive blog comments". American journalism review, v. 31, n. 1, 16 pp.

http://www.ajr.org/article_printable.asp?id=4681

http://go.galegroup.com/ps/anonymous?id=GALE\%7CA194529311 
Guallar, Javier; Suau, Jaume; Ruiz-Caballero, Carlos; Sáez, Albert; Masip, Pere (2016). “Re-dissemination of news and public debate on social networks". El profesional de la información, v. 25, n. 3, pp. 358-366.

https://doi.org/10.3145/epi.2016.may.05

Habermas, Jürgen (1984). The theory of communicative action. Vol. 1. Reason and the rationalization of society. Boston: Beacon Press. ISBN: 0807015075

http://www.dphu.org/uploads/attachements/books/books_2795_0.pdf

Habermas, Jürgen (1987). The theory of communicative action. Vol. 2. Lifeworld and system: A critique of functionalist reason. Boston: Beacon Press. ISBN: 9780807014011

https://uniteyouthdublin.files.wordpress.com/2015/01/4421-the_theory_of_communicative.pdf

Habermas, Jürgen (1989). The structural transformation of the public sphere: An inquiry into a category of bourgeois society. Cambridge, Mass: MIT Press. ISBN: 9780262081801

https://pages.uoregon.edu/koopman/courses_readings/phil123-net/publicness/habermas_structural_trans_pub_sphere.pdf

Habermas, Jürgen (1998). Conciencia moral y acción comunicativa. Barcelona: Península, 1998. ISBN: 9788474324488

Habermas, Jürgen (2003). La ética del discurso y la cuestión de la verdad. Barcelona: Paidós. ISBN: 9788449314483

Habermas, Jürgen (2006). "Political communication in media society: Does democracy still enjoy an epistemic dimension? The impact of normative theory on empirical research". Communication theory, v. 16, n. 4, pp. 411-426.

https://doi.org/10.1111/j.1468-2885.2006.00280.x

Haciyakupoglu, Gulizar; Zhang, Weiyu (2015). "Social media and trust during the Gezi protests in Turkey". Journal of computer-mediated communication, v. 20, n. 4, pp. 450-466.

https://doi.org/10.1111/jcc4.12121

Haim, Mario; Graefe, Andreas; Brosius, Hans-Bernd (2018). "Burst of the filter bubble?: Effects of personalization on the diversity of Google News". Digital journalism, v. 6, n. 3, pp. 330-343.

https://doi.org/10.1080/21670811.2017.1338145

Haines, Russell; Hough, Jill; Cao, Lan; Haines, Douglas (2014). "Anonymity in computer--mediated communication: More contrarian ideas with less influence". Group decision and negotiation, v. 23, n. 4, pp. 765-786.

https://doi.org/10.1007/s10726-012-9318-2

Hall, Peter A. (2002). "Great Britain: The role of Government and the distribution of social capital”. In: Putnam, Robert D. (ed.) Democracies in flux: The evolution of social capital in contemporary society. Oxford: Oxford University Press, pp. 21-57. ISBN: 9780195150896

https://doi.org/10.1093/0195150899.001.0001

Hanson, Gary; Haridakis, Paul (2008). "YouTube users watching and sharing the news: A uses and gratifications approach". The journal of electronic publishing, v. 11, n. 3.

http://dx.doi.org/10.3998/3336451.0011.305

Hartley, John; Green, Joshua (2006). "The public sphere on the beach". European journal of cultural studies, v. 9, n. 3, pp. 341-362.

https://doi.org/10.1177/1367549406066077

Heimbach, Irina; Schiller, Benjamin; Strufe, Thorsten; Hinz, Oliver (2015). "Content virality on online social networks: empirical evidence from Twitter, Facebook, and Google+ on German news websites". In: Proceedings of the $26^{\text {th }}$ ACM Conf on hypertext \& social media. ISBN:

https://dl.acm.org/citation.cfm?id=2791032

Heinbach, Dominique; Ziegele, Marc; Quiring, Oliver (2018). "Sleeper effect from below: Long-term effects of source credibility and user comments on the persuasiveness of news media". New media \& society, v. 20, n. 12, pp. 4765-4786. https://doi.org/10.1177/1461444818784472

Hermida, Alfred (2010). "Twittering the news - The emergence of ambient journalism”. Journalism practice, v. 4, n. 3, pp. 297-308.

https://www.jour.auth.gr/wp-content/uploads/2015/06/Hermida.pdf

Hermida, Alfred (2013). "\#Journalism: Reconfiguring journalism research about Twitter, one tweet at a time". Digital journalism, v. 1, n. 3, pp. 295-313.

https://doi.org/10.1080/21670811.2013.808456

Hermida, Alfred; Fletcher, Fred; Korell, Darryl; Logan, Donna (2012). "Share, like, recommend". Journalism studies, v. 13, n. 5-6, pp. 815-824.

https://doi.org/10.1080/1461670X.2012.664430 
Hermida, Alfred; Lewis, Seth C.; Zamith, Rodrigo (2014). “Sourcing the Arab Spring: A case study of Andy Carvin's sources on Twitter during the Tunisian and Egyptian revolutions". Journal of computer-mediated communication, v. 19, n. 3, pp. 479-499.

https://doi.org/10.1111/jcc4.12074

Hermida, Alfred; Thurman, Neil (2008). "A clash of cultures. The integration of user-generated content within professional journalistic frameworks at British newspaper websites". Journalism practice, v. 2, n. 3, pp. 343-356.

https://doi.org/10.1080/17512780802054538

Herrera-Damas, Susana; Hermida, Alfred (2014). “Tweeting but not talking: The missing element in talk radio's institutional use of Twitter". Journal of broadcasting \& electronic media, v. 58, n. 4, pp. 481-500.

https://doi.org/10.1080/08838151.2014.966361

Himelboim, Itai; McCreery, Stephen; Smith, Marc (2013). "Birds of a feather tweet together: Integrating network and content analyses to examine cross-ideology exposure on twitter". Journal of computer-mediated communication, v. 18, n. 2, pp. 40-60.

https://doi.org/10.1111/jcc4.12001

Holbert, R. Lance; Garrett, R. Kelly; Gleason, Laurel S. (2010). "A new era of minimal effects? A response to Bennett and Iyengar". Journal of communication, v. 60, n. 1, pp. 15-34.

https://doi.org/10.1111/j.1460-2466.2009.01470.x

https://rkellygarrett.com/wp-content/uploads/2014/05/Holbert-et-al.-New-era-of-minimal-effects.pdf

Holton, Avery; Baek, Kang; Coddington, Mark; Yaschur, Carolyn (2014). "Seeking and sharing: Motivations for linking on Twitter". Communication research reports, n. 31, pp. 33-40.

https://doi.org/10.1080/08824096.2013.843165

Hsueh, Mark; Yogeeswaran, Kumar; Malinen, Sanna (2015). “Leave your comment below': Can biased online comments influence our own prejudicial attitudes and behaviors?" Human communication research, v. 41, n. 4, pp. 557-576.

https://doi.org/10.1111/hcre.12059

Hu, Mengdie; Liu, Shixia; Wei, Furu; Wu, Yingcai; Stasko, John; Ma, Kwan-Liu (2012). "Breaking news on Twitter". In: Proceedings of the SIGCHI conference on human factors in computing systems.

https://dl.acm.org/citation.cfm?id=2208672

Humanes, María-Luisa (2016). “Exposición selectiva, partidismo y polarización de las audiencias de los medios en España". In: Casero, Andreu (coord.). Periodismo y democracia en el entorno digital. Madrid: SEP, pp. 37-52. ISBN: 97884 60669456

http://www.periodistica.es/sep2016r/images/pdf/Periodismo-y-Democracia.pdf

Hwang, Hyunseo; Kim, Youngju; Kim, Yeojin (2018). “Influence of discussion incivility on deliberation: An examination of the mediating role of moral indignation". Communication research, v. 45, n. 2, pp. 213-240.

https://doi.org/10.1177/0093650215616861

Ihlebaek, Karoline-Andrea; Krumsvik, Arne H. (2015). "Editorial power and public participation in online newspapers". Journalism, v. 16, n. 4, pp. 470-487.

https://doi.org/10.1177/1464884913520200

Inglehart, Ronald (1997). Modernization and postmodernization: Cultural, economic and political change in 43 Societies. Princeton: Princeton University. ISBN: 9780691011806

lyengar, Shanto; Hahn, Kyu S. (2009). "Red media, blue media: Evidence of ideological selectivity in media use". Journal of communication, v. 59, n. 1, pp. 19-39.

https://doi.org/10.1111/j.1460-2466.2008.01402.x

Jeffries, Stuart (2016). Grand Hotel Abyss. The lives of the Frankfurt School. London-New York: Verso Books. ISBN: 978 1784785680

Jenkins, Henry; Ford, Sam; Green, Joshua (2013). Spreadable media. New York: New York University Press. ISBN: 9780 814743508

Jensen, J. Linaa (2006). “The Minnesota e-democracy project: Mobilising the mobilised?”. In: Oates, S.; Owen, D.; Gibson, R. (eds.). The Internet and politics. Citizens, voters and activists. London: Routledge, pp. 39-58. ISBN: 9780415347846

Kalogeropoulos, Antonis; Negredo, Samuel; Picone, Ike; Nielsen, Rasmus-Kleis (2017). "Who shares and comments on news?: A cross-national comparative analysis of online and social media participation". Social media + society, $\mathrm{v}$. 3, n. 4, pp. 1-12.

https://doi.org/10.1177/2056305117735754 
Kalsnes, Bente; Larsson, Anders-Olof (2018). "Understanding news sharing across social media”. Journalism studies, v. 19, n. 11, pp. 1669-1688.

https://doi.org/10.1080/1461670X.2017.1297686

Karpowitz, Christopher F.; Raphael, Chad (2014). "Introduction". Deliberation, democracy, and civic forums: Improving equality and publicity. Cambridge: Cambridge University Press. ISBN: 9781107046436

Keane, John (1991). The media and democracy. Cambridge: Polity Press. ISBN: 9780745608044

Khaldarova, Irina; Pantti, Mervi (2016). "Fake news. The narrative battle over the Ukrainian conflict". Journalism practice, v. 10, n. 7, pp. 891-901.

https://doi.org/10.1080/17512786.2016.1163237

Kim, Hyun-Suk (2015). "Attracting views and going viral: How message features and newssharing channels affect health news diffusion". Journal of communication, v. 65, n. 3, pp. 512-534.

https://doi.org/10.1111/jcom.12160

Kim, Min-Gyu; Kim, Joohan (2012). “Comparing the effects of newspaper, TV news, and the internet news on the evaluation of a major political candidate: Latent growth modeling with longitudinal panel data from the 2007 presidential campaign in South Korea". International journal of public opinion research, v. 24, n. 1, pp. 62-78.

https://doi.org/10.1093/ijpor/edr046

Klinger, Ulrike; Svensson, Jakob (2015). "The emergence of network media logic in political communication: A theoretical approach". New media \& society, v. 17, n. 8, pp. 1241-1257.

https://doi.org/10.1177/1461444814522952

Kormelink, Tim-Groot; Costera-Meijer, Irene (2018). "What clicks actually mean: Exploring digital news user practices". Journalism, v. 19, n. 5, pp. 668-683.

https://doi.org/10.1177/1464884916688290

Kovach, Bill; Rosenstiel, Tom (2001). The elements of journalism: what news people should know and the public should expect. New York: Three Rivers. ISBN: 9780804136785

Krumsvik, Arne H. (2013). "Towards a typology of strategies for user involvement". In: Friedrichsen, M.; Mühl-Benninghaus, W. (eds.). Handbook of social media management. Media business and innovation. Berlin: Springer, pp. 657-670. ISBN: 9783642288968

Ksiazek, Thomas B. (2018). "Commenting on the news: Explaining the degree and quality of user comments on news websites". Journalism studies, v. 19, n. 5, pp. 650-673.

https://doi.org/10.1080/1461670X.2016.1209977

Ksiazek, Thomas B.; Peer, Limor; Zivic, Andrew (2015). "Discussing the news: Civility and hostility in user comments". Digital journalism, v. 3, n. 6, pp. 850-870.

https://doi.org/10.1080/21670811.2014.972079

Kümpel, Anna-Sophie; Karnowski, Veronika; Keyling, Till (2015). "News sharing in social media: A review of current research on news sharing users, content, and networks". Social media + society, v. 1, n. 2, pp. 1-14.

https://doi.org/10.1177/2056305115610141

Lampinen, Airi (2015). “Deceptively simple: Unpacking the notion of 'sharing'”. Social media + society, v. 1, n. 1. https://doi.org/10.1177/2056305115578135

Lanham, Richard A. (2006). The economics of attention: Style and substance in the age of information. Chicago, IL: University of Chicago Press. ISBN: 9780226468822

Larsson, Anders-Oloff (2012). "Interactivity on Swedish newspaper websites: What kind, how much and why?". Convergence: The international journal of research into new media technologies, v. 18, n. 2, pp. 195-213.

https://doi.org/10.1177/1354856511430184

Larsson, Anders-Olof (2018). “I shared the news today, oh boy': News provision and interaction on Facebook". Journalism studies, v. 19, n. 1, pp. 43-61.

https://doi.org/10.1080/1461670X.2016.1154797

Lasorsa, Dominic L.; Lewis, Seth C.; Holton, Avery E. (2012). “Normalizing Twitter. Journalism practice in an emerging communication space". Journalism studies, v. 13, n. 1, pp. 19-36.

https://doi.org/10.1080/1461670X.2011.571825

Lazarsfeld, Paul-Felix; Berelson, Bernard; Gaudet, Hazel (1948). The people's choice: How the voter makes up his mind in a presidential campaign. New York, NY: Columbia University Press. ISBN: 9780231085830

Lee, Chei-Sian; Ma, Long (2012). “News sharing in social media: The effect of gratifications and prior experience". Com- 
puters in human behavior, v. 28, n. 2, pp. 331-339.

https://www.sciencedirect.com/science/article/pii/S074756321100210X?via\%3Dihub

Lee, Eun-Ju; Jang, Yoon-Jae (2010). "What do others' reactions to news on Internet portal sites tell us? Effects of presentation format and readers' need for cognition on reality perception". Communication research, v. 37, n. 6, pp. 825-846. https://doi.org/10.1177/0093650210376189

Lewis, Seth C.; Holton, Avery E.; Coddington, Mark (2014). "Reciprocal journalism”. Journalism practice, v. 8, n. 2, pp. 229-241.

https://doi.org/10.1080/17512786.2013.859840

Lewis, Seth C.; Molyneux, Logan (2018). "A decade of research on social media and journalism: Assumptions, blind spots, and a way forward". Media and communication, v. 6, n. 4, pp. 11-23.

https://doi.org/10.17645/mac.v6i4.1562

Lichterman, Joseph (2016). Twitter has outsized influence, but it doesn't drive much traffic for most news orgs, a new report says. Nieman Lab.

http://www.niemanlab.org/2016/04/twitter-has-outsized-influence-but-it-doesnt-drive-much-traffic-for-most-newsorgs-a-new-report-says

Lietsala, Katri; Sirkkunen, Esa (2008). Social media: Introduction to the tools and processes of participatory economy. Tampere: Tampere University Press. ISBN: 9789514473746

https://tampub.uta.fi/bitstream/handle/10024/65560/978-951-44-7320-3.pdf

Liu, Qian; Zhou, Mi; Zhao, Xin (2015). “Understanding news 2.0: A framework for explaining the number of comments from readers on online news". Information and management, v. 52, n. 7, pp. 764-776.

http://doi.org/10.1016/j.im.2015.01.002

Livingstone, Sonia (2005). "On the relation between audiences and publics: Why audience and public". In: Livingstone, Sonia (ed.). Audiences and publics: When cultural engagement matters for the public sphere. Bristol: Intellect Books, pp. 17-41. ISBN: 1841501298

https://core.ac.uk/download/pdf/92597.pdf

Livingstone, Sonia (2013). "The participation paradigm in audience research". The communication review, v. 16, n. 1-2, pp. 21-30.

https://doi.org/10.1080/10714421.2013.757174

Loader, Brian D.; Mercea, Dan (2012). Social media and democracy. Oxon: Routledge. ISBN: 9780415683708

Loke, Jaime (2012). “Old turf, new neighbors: Journalists' perspectives on their new shared space”. Journalism practice, v. 6, n. 2, pp. 233-249.

https://doi.org/10.1080/17512786.2011.616649

Losey, James (2014). "The Anti-counterfeiting trade agreement and European civil society: A Case study of networked advocacy". Journal of information policy, v. 4, pp. 205-227.

https://goo.gl/AC8to9

Ma, Long; Lee, Chei-Sian; Goh, Dion-Hoe-Lian (2013). "Investigating influential factors influencing users to share news in social media: A diffusion of innovations perspective". In: Proceedings of the $13^{\text {th }}$ ACM/IEEE-CS Joint conference on digital libraries.

https://dl.acm.org/citation.cfm?id=2467749

Ma, Long; Lee, Chei-Sian; Goh, Dion-Hoe-Lian (2014). "Understanding news sharing in social media: An explanation from the diffusion of innovations theory". Online information review, v. 38, n. 5, pp. 598-615.

https://doi.org/10.1108/OIR-10-2013-0239

Manosevitch, Idit; Tenenboim, Ori (2017). "The multifaced role of user-generated content in news websites. An analytical framework". Digital journalism, v. 5, n. 6, pp. 731-752.

https://doi.org/10.1080/21670811.2016.1189840

Masip, Pere (2011) “Comentarios de las noticias: la pesadilla de los cibermedios”. Anuario ThinkEPI, v. 5, pp. 106-111. https://recyt.fecyt.es/index.php/ThinkEPI/article/viewFile/30478/16044

Masip, Pere; Guallar, Javier; Suau, Jaume; Ruiz-Caballero, Carlos; Peralta, Miquel (2015a). “News and social networks: audience behavior". El profesional de la información, v. 24, n. 4, pp. 363-370.

https://doi.org/10.3145/epi.2015.jul.02

Masip, Pere; Guallar, Javier; Suau, Jaume; Ruiz-Caballero, Carlos; Peralta, Miquel (2015b). "Active audiences and journalism: Involved citizens or motivated consumers?". Brazilian journalism research, v. 11, pp. 234-255. 
https://doi.org/10.25200/BJR.v11n1.2015.815

Masip, Pere; Ruiz-Caballero, Carlos; Suau, Jaume (2015). “Journalists hegemonies in the age of journalism participation: the audience's perspective". IAMCR int/ conf, Montreal (Canada), July 12-15.

Masip, Pere; Ruiz-Caballero, Carles; Suau, Jaume (2019). “Contesting professional procedures of journalists: public conversation on Twitter after Germanwings accident". Digital journalism, Online first.

https://doi.org/10.1080/21670811.2018.1546551

Masip, Pere; Suau-Martínez, Jaume; Ruiz-Caballero, Carlos (2018). "Questioning the selective exposure to news: understanding the impact of social networks on political news consumption". American behavioral scientist, v. 62, n. 3, pp. 300-319. https://doi.org/10.1177/0002764217708586

Massey, Brian L.; Levy, Mark R. (1999). “'Interactive’ online journalism at English-language web newspapers in Asia: A dependency theory analysis". International communication gazette, v. 61, n. 6, pp. 523-535.

https://doi.org/10.1177/0016549299061006005

Mcallister, Ian (2007). "The personalization of politics". In: The Oxford handbook of political behavior. Oxford Handbooks Online. ISBN: 9780199270125

Melucci, Alberto (1996). Challenging codes: Collective action in the information age. Cambridge: Cambridge University Press. ISBN: 9780521578431

Messing, Solomon; Westwood, Sean J. (2014) "Selective exposure in the age of social media: Endorsements Trump partisan source affiliation when selecting news online". Communication research, v. 41, n. 8, p. 1042-1063.

https://doi.org/10.1177/0093650212466406

Meyer, Hans K.; Carey, Michael-Clay (2014). “In moderation. Examining how journalists' attitudes toward online comments affect the creation of communit". Journalism practice, v. 8, n. 2, pp. 213-228.

https://doi.org/10.1080/17512786.2013.859838

Min, Seong-Jae (2007). "Online vs. face-to-face deliberation: Effects on civic engagement". Journal of computer-mediated communication, v. 12, n. 4, pp. 1369-1387.

https://doi.org/10.1111/j.1083-6101.2007.00377.x

Mitchell, Amy; Holcomb, Jesse; Weisel, Rachel (2016). State of news media 2016. Washington, DC: Pew Research Center. http://www.pewresearch.org/wp-content/uploads/sites/8/2016/06/state-of-the-news-media-report-2016-final.pdf

Mitchell, Amy; Page, Dana (2014). State of news media 2014. Washington, DC: Pew Research Center. http://assets.pewresearch.org/wp-content/uploads/sites/13/2017/05/30142556/state-of-the-news-media-report2014-final.pdf

Mitchelstein, Eugenia (2011). "Catharsis and community: Divergent motivations for audience participation in online newspapers and blogs". International journal of communication, v. 5, pp. 2014-2034.

https://ijoc.org/index.php/ijoc/article/viewFile/1080/672

Mouffe, Chantal (2005). On the political (Thinking in action). London: Routledge. ISBN: 9780415305211

Mouffe, Chantal (2013). Agonistics: Thinking the world politically. London: Verso. ISBN: 9781781681039

Muddiman, Ashley; Stroud, Natalie-Jomini (2017). "News values, cognitive biases, and partisan incivility in comment sections". Journal of communication, v. 67, n. 4, pp. 586-609.

https://doi.org/10.1111/jcom.12312

Naab, Teresa K.; Sehl, Annika (2017). "Studies of user-generated content: A systematic review”. Journalism, v. 18, n. 10, pp. 1256-1273.

https://doi.org/10.1177/1464884916673557

Napoli, Philip M. (2009). Navigating producer-consumer convergence: Media policy priorities in the era of user-generated and user-distributed content. New York: The Donald McGannon Communication Research Center, Fordham University. https://fordham.bepress.com/cgi/viewcontent.cgi?article=1004\&context=mcgannon_research

Nerone, John (2009). "The death (and rebirth?) of working-class journalism”. Journalism, v. 10, n. 3, pp. $353-355$. https://doi.org/10.1177/1464884909102596

Newman, Nic; Dutton, William H.; Blank, Grant (2012). "Social media in the changing ecology of news: The fourth and fifth estates in Britain". International journal of internet science, v. 7, n. 1, pp. 6-22.

http://www.ijis.net/ijis7_1/ijis7_1_newman_et_al.pdf

Newman, Nic; Fletcher, Richard; Kalogeropoulos, Antonis; Levy, David A. L.; Nielsen, Rasmus-Kleis (2018). Digital news report 2018. Oxford: Reuters Institute for the Study of Journalism. 
http://media.digitalnewsreport.org/wp-content/uploads/2018/06/digital-news-report-2018.pdf

Newman, Nic; Fletcher, Richard; Levy, David A. L.; Nielsen, Rasmus-Kleis (2016). Digital news report: 2016. Oxford: Reuters Institute for the Study of Journalism.

http://media.digitalnewsreport.org/wp-content/uploads/2018/11/Digital-News-Report-2016.pdf

Newman, Nic; Levy, David A. L. (2014). Reuters Institute Digital News Report 2014. Oxford: Reuters Institute for the Study of Journalism.

https://bit.ly/2UueF7x

Nielsen, Rasmus-Kleis; Schrøder, Kim-Christian (2014). "The relative importance of social media for accessing, finding, and engaging with news". Digital journalism, v. 2, n. 4, pp. 472-489.

https://doi.org/10.1080/21670811.2013.872420

Nilsson, Monica-Löfgren; Örnebring, Henrik (2016). “Journalism under threat”. Journalism practice, v. 10, n. 7, pp. 880890.

https://doi.org/10.1080/17512786.2016.1164614

Nip, Joyce Y. M. (2006). “Exploring the second phase of public journalism”. Journalism studies, v. 7, n. 2, pp. $212-236$. https://doi.org/10.1080/14616700500533528

Nisbet, Matthew C.; Scheufele, Dietram A. (2004). "Political talk as a catalyst for online citizenship". Journalism \& mass communication quarterly, v. 81, n. 4, pp. 877-896.

https://doi.org/10.1177/107769900408100410

Norris, Pippa (2000). A virtuous circle. New York: Cambridge University Press. ISBN: 9780521793643

Norris, Pippa (2002). Democratic phoenix: Reinventing political activism. Cambridge: Cambridge University Press. ISBN: 9780511610073

O’Neill, Paul (2007). Curating subjects. Amsterdam: Open Editions. ISBN: 9780949004161

O’Sullivan, John; Heinonen, Ari (2008). "Old values, new media. Journalism role perceptions in a changing world”. Journalism practice, v. 2, n. 3, pp. 357-371.

https://doi.org/10.1080/17512780802281081

Olmstead, Kenny; Mitchell, Ami; Rosenstiel, Tom (2011). Navigating news online: Where people go, how they get there and what lures them away. Pew Research Center.

http://www.pewresearch.org/wp-content/uploads/sites/8/legacy/NIELSEN-STUDY-Copy.pdf

Owen, Laura-Hazard (2018). "Here's a first attempt to quantify the extent of Europe's fake news problema". Nieman Journalism Lab.

http://www.niemanlab.org/2018/01/heres-a-first-attempt-to-quantify-the-extent-of-europes-fake-news-problem

Oz, Mustafa; Zheng, Pei; Chen, Gina-Masullo (2018). “Twitter versus Facebook: Comparing incivility, impoliteness, and deliberative attributes". New media \& society, v. 20, n. 9, pp. 3400-3419.

https://doi.org/10.1177/1461444817749516

Papacharissi, Zizi (2002). "The virtual sphere: The Internet as a public sphere”. New media \& society, v. 4, n. 1, pp. 9-27. https://doi.org/10.1177/14614440222226244

Papacharissi, Zizi (2004). "Democracy online: Civility, politeness, and the democratic potential of online political discussion groups". New media and society, v. 6, n. 2, pp. 259-283.

https://doi.org/10.1177/1461444804041444

Papacharissi, Zizi (2010). A private sphere: Democracy in a digital age. Cambridge: Polity Press. ISBN: 9780745645254

Papacharissi, Zizi (2015a). Affective publics: Sentiment, technology, and politics. Oxford: Oxford University Press. ISBN: 9780199999736

Papacharissi, Zizi (2015b). "Toward new journalism. Affective news, hybridity, and liminal spaces". Journalism studies, v. 16, n. 1, pp. 27-40.

https://doi.org/10.1080/1461670X.2014.890328

Pariser, Eli (2011). The filter bubble: What the Internet is hiding from you. UK: Penguin. ISBN: 9780241954522

Pasquale, Frank (2015). The black box society: The secret algorithms that control money and information. Cambridge, MA: Harvard University Press. ISBN: 9780674368279

Peacock, Cynthia; Scacco, Joshua M.; Stroud, Natalie-Jomini (2017). "The deliberative influence of comment section structure". Journalism, Online first. 
https://doi.org/10.1177/1464884917711791

Peterson, Erik; Goel, Sharad; lyengar, Shanto (2018). “Echo chambers and partisan polarization: Evidence from the 2016 presidential campaign". Unpublished manuscript.

https://5harad.com/papers/selective-exposure.pdf

Persily, Nathaniel (2017). “Can democracy survive the Internet?”. Journal of democracy, v. 28, n. 2, pp. 63-76. https://www.journalofdemocracy.org/article/can-democracy-survive-the-internet

Pharr, Susan J.; Robert D. Putnam (eds.) (2000). Disaffected democracies: What's troubling the Trilateral countries. Princeton: Princeton University Press. ISBN: 9780691049243

Picone, Ike; De-Wolf, Ralf; Robijt, Sarie (2016). "Who shares what with whom and why?: News sharing profiles amongst Flemish news users". Digital journalism, v. 4, n. 7, pp. 921-932.

https://doi.org/10.1080/21670811.2016.1168708

Press, Andrea L.; Livingstone, Sonia (2006). "Taking audience research into the age of new media: Old problems and new challenges". In: White, M; Schwoch, J. (eds.) Questions of method in cultural studies. Oxford: Blackwell Publishing, pp. 175-200. ISBN: 9780631229780

https://www.academia.edu/29375452/Taking_Audience_Research_into_the_Age_of_New_Media_Old_Problems_ and_New_Challenges

Press, Andrea L.; Williams, Bruce A. (2010). The new media environment: An introduction. Oxford: Wiley-Blackwell. ISBN: 9781405127684

Prior, Markus (2007). Post-broadcast democracy. How media choice increases inequality in political involvement and polarizes elections. Cambridge: Cambridge University Press. ISBN: 9780521675338

Prior, Markus (2013). "Media and political polarization”. Annual review of political science, v. 16, pp. 101-127. https://doi.org/10.1146/annurev-polisci-100711-135242

Prochazka, Fabian; Weber, Patrick; Schweiger, Wolfgang (2018). "Effects of civility and reasoning in user comments on perceived journalistic quality". Journalism studies, n. 19, n. 1, pp. 62-78.

https://doi.org/10.1080/1461670X.2016.1161497

Purcell, Kristen; Rainie, Lee; Mitchell, Amy; Rosenstiel, Tom (2010). Understanding the participatory news consumer. Pew Research Center's Internet \& American Life Project.

http://www.pewinternet.org/2010/03/01/understanding-the-participatory-news-consumer

Quandt, Thorsten (2018). “Dark participation”. Media and communication, v. 6, n. 4, pp. 36-48.

https://doi.org/10.17645/mac.v6i4.1519

Quattrociocchi, Walter; Scala, Antonio; Sunstein, Cass R. (2016). Echo chambers on Facebook, 15 pp.

https://ssrn.com/abstract=2795110

https://doi.org/10.2139/ssrn.2795110

Rainie, Lee; Wellman, Barry (2012). Networked. Cambridge MA: The MIT Press. ISBN: 9780262526166

Rains, Stephen A. (2007). "The impact of anonymity on perceptions of source credibility and influence in computer-mediated group communication: A test of two competing hypotheses". Communication research, v. 34, n. 1, pp. $100-125$. https://doi.org/10.1177/0093650206296084

Reader, Bill (2012). "Free press vs. free speech? The rhetoric of 'civility' in regard to anonymous online comments". Journalism \& mass communication quarterly, v. 89, n. 3, pp. 495-513.

https://doi.org/10.1177/1077699012447923

Reich, Zvi (2011). "User comments: The transformation of participatory space”. In: Singer, Jane B. (eds.). Participatory journalism: Guarding open gates at online newspapers. Malden, MA: Wiley-Blackwell, pp. 96-117. ISBN: 9781444 332261

Rheingold, Howard (2002). Smart mobs: The next social revolution. Cambridge MA: Perseus Publishing. ISBN: 9780 738208619

Richardson, John E.; Stanyer, James (2011). "Reader opinion in the digital age: Tabloid and broadsheet newspaper websites and the exercise of political voice". Journalism, v. 12, n. 8, pp. 983-1003.

https://doi.org/10.1177/1464884911415974

Robertson, Scott P.; Vatrapu, Ravi K.; Medina, Richard (2010). “Off the wall political discourse: Facebook use in the 2008 U.S. presidential election". Information polity, v. 15, n. 1-2, pp. 11-31.

https://doi.org/10.3233/IP-2010-0196 
https://www.cbs.dk/files/cbs.dk/52815712.pdf

Robinson, Sue (2010) "Traditionalists vs. convergers: Textual privilege, boundary work, and the journalist-audience relationship in the commenting policies of online news sites". Convergence: The international journal of research into new media technologies, v. 16, n. 1, pp. 125-143.

https://doi.org/10.1177/1354856509347719

Rojas, Hernando (2010). "'Corrective' actions in the public sphere: How perceptions of media and media effects shape political behaviors". International journal of public opinion research, v. 22, n. 3, pp. 343-363.

https://doi.org/10.1093/ijpor/edq018

Rosengard, Dana; Tucker-McLaughlin, Mary; Brown, Tim (2014). "Students and social news: How college students share news through social media”. Electronic news, v. 8, n. 2, pp. 120-137.

https://doi.org/10.1177/1931243114546448

Rowe, Ian (2014). "Civility 2.0: A comparative analysis of incivility in online political discussion". Information, communication \& society, v. 18, n. 2, pp. 121-138.

https://doi.org/10.1080/1369118X.2014.940365

Rowe, lan (2015). "Deliberation 2.0: Comparing the deliberative quality of online news user comments across platforms". Journal of broadcasting \& electronic media, v. 59, n. 4, pp. 539-555.

https//doi.org/10.1080/08838151.2015.1093482

Rudat, Anja; Buder, Jürgen; Hesse, Friedrich W. (2014). "Audience design in Twitter: Retweeting behavior between informational value and followers' interests". Computers in human behavior, v. 35, pp. 132-139.

https://doi.org/10.1016/j.chb.2014.03.006

Ruiz-Caballero, Carlos; Domingo, David; Micó-Sanz, Josep-Lluís; Díaz-Noci, Javier; Meso, Koldo; Masip, Pere (2011). "Public sphere 2.0? The democratic qualities of citizen debates in online newspapers". International journal of press/ politics, v. 16, n. 4, pp. 463-487.

https://doi.org/10.1177/1940161211415849

Ruiz-Caballero, Carlos; Masip, Pere; Micó-Sanz, Josep-Lluís; Díaz-Noci, Javier; Domingo, David (2010). “Conversation 2.0. and democracy. An analysis of reader's comments in Catalan online newspapers". Communication and society, v. 23, n. 2, pp. 7-39.

https://www.unav.es/fcom/communication-society/en/resumen.php?art_id=360

Rutherford, Jennifer (2003). "Zombie categories: Interview with Ulrich Beck". In: Beck, Ulrich; Beck-Gernsheim, Elisbeth. Individualization: Institutionalized individualism and its social and political consequences. London: Sage, pp. 202-213. ISBN: 9780761961123

Santana, Arthur D. (2011). “Online readers' comments represent new opinion pipeline”. Newspaper research journal, v. 32, n. 3, pp. 66-81.

https://doi.org/10.1177/073953291103200306

Santana, Arthur D. (2013). "Virtuous or vitriolic. The effect of anonymity on civility in online newspaper reader comment boards" Journalism practice, v. 8, n. 1, pp. 18-33.

https://doi.org/10.1080/17512786.2013.813194

Santana, Arthur D. (2014). “Controlling the conversation”. Journalism studies, v. 17, n. 2, pp. 141-158. https://doi.org/10.1080/1461670X.2014.972076

Sartori, Giovanni (1998). Homo videns. Madrid: Taurus. ISBN: 9788466342513

Schäfer, Mike S. (2015). "Digital public sphere”. In: Mazzoleni, G. et al. (eds.). The international encyclopedia of political communication. London: Wiley Blackwell, pp. 322-328.

https://doi.org/10.1002/9781118541555.wbiepc087

Schmidt, Jan-Hinrik (2014). "Twitter and the rise of personal publics". In: Weller, Katrin et al. (eds.). Twitter \& society. New York: Peter Lang, pp. 3-14. ISBN: 9781433121692

https://bit.ly/2FObfV6

Schrøder, Kim-Christian (2013). "From dogmatism to open-mindedness? Historical reflections on methods in audience reception research". The communication review, v. 16, n. 1-2, pp. 40-50.

https://doi.org/10.1080/10714421.2013.757485

Schrøder, Kim-Christian (2015). “News media old and new”. Journalism studies, v. 16, n. 1, pp. 60-78. https://doi.org/10.1080/1461670X.2014.890332

Schrøder, Kim-Christian; Drotner, Kristen; Kline, Stephen; Murray, Catherine (2003). Researching audiences. A practical 
guide to methods in media audience analysis. London: Arnold. ISBN: 9780340762745

Schwering, Markus (2014). “Internet and public sphere. What the web can't do. Jürgen Habermas interviewed by Markus Schwering". Interview published in the "feulleton" of the Frankfurter Rundschau, 14/15 June.

https://www.resetdoc.org/story/internet-and-public-sphere-what-the-web-cant-do

Sherrick, Brett; Hoewe, Jennifer (2018). "The effect of explicit online comment moderation on three spiral of silence outcomes". New media \& society, v. 20, n. 2, pp. 453-474.

https://doi.org/10.1177/1461444816662477

Shoemaker, Pamela; Vos, Tim P. (2009). Gatekeeping theory. New York: Routledge. ISBN: 9780415981385

Singer, Jane B. (2008). "Online journalists. Foundations for research into their changing roles". Journal of computer-mediated communication, v. 4, n. 1.

http://www.ascusc.org/jcmc/vol4/issue1/singer.html

Singer, Jane B. (2010). “Quality control: Perceived effects of user-generated content on newsroom norms, values and routines" Journalism practice, v. 4, n. 2, pp. 127-142.

https://doi.org/10.1080/17512780903391979

Singer, Jane B. (2014). "User-generated visibility: Secondary gatekeeping in a shared media space". New media \& society, v. 16, n. 1 , pp. $55-73$.

https://doi.org/10.1177/1461444813477833

Singer, Jane B.; Domingo, David; Heinonen, Ari; Hermida, Alfred; Paulussen, Steve; Quandt, Thorsten; Reich, Zvi; Vujnovic, Marina (2011). Participatory journalism: Guarding open gates at online newspapers. Oxford: Wiley-Blackwell. ISBN: 9781444332261

Soffer, Oren; Gordoni, Galit (2017). “Opinion expression via user comments on news websites: Analysis through the perspective of the spiral of silence". Information, communication and society, v. 21, n. 3, pp. 388-403.

https://doi.org/10.1080/1369118X.2017.1281991

Sparks, Colin; Tulloch, John (2000). Tabloid tales. London: Rowman \& Littlefield Publishers. ISBN: 9780847695720

Springer, Nina; Engelmann, Ines; Pfaffinger, Christian (2015). “User comments: Motives and inhibitors to write and read". Information, communication and society, v. 18, n. 7, pp. 798-815.

https://doi.org/10.1080/1369118X.2014.997268

Steiner, George (2004). La idea d'Europa. Barcelona: Arcàdia. ISBN: 9788493409609

Steinfeld, Nili; Samuel-Azran, Tal; Lev-On, Azi (2016). “User comments and public opinion: Findings from an eye-tracking experiment". Computers in human behavior, v. 61, pp. 63-72.

https://doi.org/10.1016/j.chb.2016.03.004

Stelter, Brian (2008). "Finding political news online, the young pass it on". The New York Times, March $27^{\text {th }}$. http://www.nytimes.com/2008/03/27/us/politics/27voters.html

Stieglitz, Stefan; Dang-Xuan, Linh (2013). “Emotions and information diffusion in social media - Sentiment of microblogs and sharing behavior". Journal of management information systems, v. 29, n. 4, pp. 217-248.

https://doi.org/10.2753/MIS0742-1222290408

Stroud, Natalie-Jomini (2010) “Polarization and partisan selective exposure". Journal of communication, v. 60, n. 3, pp. 556-576.

https://doi.org/10.1111/j.1460-2466.2010.01497.x

Stroud, Natalie-Jomini; Muddiman, Ashley; Scacco, Joshua M. (2016). “Like, recommend, or respect? Altering political behavior in news comment sections". New media \& society, v. 19, n. 11, pp. 1727-1743.

https://doi.org/10.1177/1461444816642420

Stroud, Natalie-Jomini; Scacco, Joshua M.; Muddiman, Ashley; Curry, Alexander L. (2014). "Changing deliberative norms on news organizations' Facebook sites". Journal of computer-mediated communication, v. 20, n. 2, pp. $188-203$. https://doi.org/10.1111/jcc4.12104

Suau, Jaume (2015). Citizens and online media participation. Attitudes and motivations towards participatory journalism and other online practices in London and Barcelona. PhD thesis. Barcelona, University Ramon Llull.

Suau, Jaume; Masip, Pere (2014). "Exploring participatory journalism in mediterranean countries". Journalism practice, v. 8, n. 6, pp. 670-687.

https://doi.org/10.1080/17512786.2013.865964

Suau, Jaume; Masip, Pere; Ruiz-Caballero, Carlos (2019) (forthcoming). “Missing the big wave: Citizens' discourses 
against the participatory formats adopted by news media". Journalism practice.

Sujin, Choi; Ji-young, Park; Woo, Park-Han (2012). "Using social media data to explore communication processes within South Korean online innovation communities". Scientometrics, v. 90, n. 1, pp. 43-56.

https://doi.org/10.1007/s11192-011-0514-7

Suler, John (2004). "The online disinhibition effect". Cyberpsychology \& behavior, v. 7, n. 3, pp. 321-326. https://doi.org/10.1089/1094931041291295

Sunstein, Cass R. (2002). Republic.com. Princeton: Princeton University Press. ISBN: 9780691070254

Sunstein, Cass R. (2001). Republic 2.0. Princeton: Princeton University Press. ISBN: 9780691143286

Sunstein, Cass R. (2017). \#Republic. Divided democracy in the age of social media. Princton: Princeton University Press. ISBN: 9781400890521

Tarde, Gabriel (1969). "The public and the crowd". In: Clark, Terry (ed.) Communication and social influence. Chicago: University of Chicago, pp. 277-296. ISBN: 9781941626047

Tenenboim, Ori; Cohen, Akiba A. (2015). "What prompts users to click and comment: A longitudinal study of online news". Journalism, v. 16, n. 2, pp. 198-217.

https://doi.org/10.1177/1464884913513996

Tewksburg, David; Rittenberg, Jason (2012). News on the Internet: Information and citizenship in the $21^{\text {st }}$ century Oxford studies in digital politics. New York: Oxford University Press. ISBN: 9780195391978

Tewksbury, David; Weaver, Andrew J.; Maddex, Brett D. (2001). “Accidentally informed: incidental news exposure on the world wide web". Journalism \& mass communication quarterly, v. 78, n. 3, pp. 533-554.

https://doi.org/10.1177/107769900107800309

Thorsen, Einar (2013). "Live blogging and social media curation: Challenges and opportunities for journalism". In: FowlerWalt, K.; Allan, S. (eds.). Journalism: New challenges. Poole, UK: Centre for Journalism \& Communication Research. Bournemouth University, pp. 123-145. ISBN: 9781910042014

Thrall, A. Trevor; Berent, Jon; Donnelly, Lana; Herrin, Wes; Paquette, Zachary; Wenglinski, Rebecca; Wyatt, Amy (2008). "Star power: Celebrity advocacy and the evolution of the public sphere". The international journal of press/politics, v. 13, n. 4, pp. 362-385.

https://doi.org/10.1177/1940161208319098

Thurman, Neil (2008). "Forums for citizen journalists? Adoption of user generated content initiatives by online news media". New media \& society, v. 10, n. 1, pp. 139-157.

https://doi.org/10.1177/1461444807085325

Tolbert, Caroline J.; Mcneal, Ramona S. (2003). “Unraveling the effects of the Internet on political participation?”. Political research quarterly, v. 56, n. 2, pp. 175-185.

https://doi.org/10.1177/106591290305600206

Trilling, Damian; Van-Klingeren, Marijn; Tsfati, Yariv (2016). "Selective exposure, political polarization, and possible mediators: Evidence from the Netherlands". International journal of public opinion research, v. 29, n. 2, pp. $189-213$. https://doi.org/10.1093/ijpor/edw003

Usher, Nikki (2017). "The appropriation / amplification model of citizen journalism: An account of structural limitations and the political economy of participatory content creation". Journalism practice, v. 11, n. 2-3, pp. 247-265.

https://doi.org/10.1080/17512786.2016.1223552

Valenzuela, Sebastián; Piña, Martina; Ramírez, Josefina (2017). “Behavioral effects of framing on social media users: How conflict, economic, human interest, and morality frames drive news sharing". Journal of communication, v. 67, n. 5, pp. 803-826.

https://doi.org/10.1111/jcom.12325

Van-Dijck, José; Nieborg, David (2009). "Wikinomics and its discontents: A critical analysis of web 2.0 business manifestos". New media \& society, v. 11, n. 5, pp. 855-874.

https://doi.org/10.1177/1461444809105356

Van-Dijck, José; Poell, Thomas (2013). “Understanding social media logic”. Media and communication, v. 1, n. 1, pp. 2-14.

http://dx.doi.org/10.17645/mac.v1i1.70

Van-Zoonen, Liesbet (2005). Entertaining the citizen: When politics and popular culture converge. Oxford: Rowman \& 
Littlefield Publishers. ISBN: 9780742529076

Vergeer, Maurice; Hermans, Liesbeth; Sams, Steven (2011). “Online social networks and micro-blogging in political campaigning: The exploration of a new campaign tool and a new campaign style". Party politics, v. 19, n. 3, pp. 477-501. https://doi.org/10.1177/1354068811407580

Villi, Mikko (2012). "Social curation in audience communities: UDC (user-distributed content) in the networked media ecosystem". Participations, v. 9, n. 2, pp. 614-632.

http://www.participations.org/Volume\%209/Issue\%202/33\%20Villi.pdf

Vos, Tim P.; Heinderyckx, François (eds.). (2015). Gatekeeping in transition. New York: Routledge Press. ISBN: 9781 317910527

Vujnovic, Marina; Singer, Jane B.; Paulussen, Steve; Heinonen, Ari; Reich, Zvi; Quandt, Thorsten; Hermida, Alfred; Domingo, David (2010). "Exploring the political-economic factors of participatory journalism". Journalism practice, v. 4, n. 3, pp. 285-296.

https://doi.org/10.1080/17512781003640588

Wahl-Jorgensen, Karin; Hanitzsch, Thomas (2009). "Introduction: On why and how we should do journalism studies". In: Wahl-Jorgensen, Karin; Hanitzsch, Thomas (eds.). The handbook of journalism studies. New York: Routledge, pp. 3-17. ISBN: 9780805863437

https://keralamediaacademy.org/wp-content/uploads/2015/02/Handbook-of-Journalism-Studies.pdf

Weber, Lori M.; Loumakis, Alysha; Bergman, James (2003). "Who participates and why?: An analysis of citizens on the internet and the mass public". Social science computer review, v. 21, n. 1, pp. 26-42.

https://doi.org/10.117/0894439302238969

Weber, Patrick (2014). "Discussions in the comments section: Factors influencing participation and interactivity in online newspapers' reader comments". New media \& society, v. 16, n. 6, pp. 941-957.

https://doi.org/10.1177/1461444813495165

Webster, Frank (2013). "What's the use of the public sphere in the age of the internet?". In: Lee, Francis L.F. et al. (eds.). Frontiers in new media research. New York: Routledge, pp. 19-38. ISBN: 9781136286858

https://doi.org/10.4324/9780203113417

Webster, James G. (2007). “Diversity of exposure". In: P. M. Napoli (ed.). Media diversity and localism: Meaning and metrics. Mahwah, NJ: Lawrence Erlbaum, pp. 309-326.

http://webster.soc.northwestern.edu/pubs/Webster\%20\%282007\%29\%20Diversity\%20of\%20Exposue.pdf

Webster, James G. (2010). "User information regimes: How social media shape patterns of consumption". Northwestern University law review, v. 104, n. 2, pp. 593-612.

https://www.researchgate.net/publication/279717654_User_information_regimes_How_social_media_shape_patterns_of_consumption

Webster, James G. (2011). "The duality of media: A structurational theory of public attention". Communication theory, v. 21, n. 1 , pp. 43-66.

https://doi.org/10.1111/j.1468-2885.2010.01375.x

Webster, James G.; Ksiazek, Thomas B. (2012). "The dynamics of audience fragmentation: Public attention in an age of digital media". Journal of communication, v. 62, n. 1, pp. 39-56.

https://doi.org/10.1111/j.1460-2466.2011.01616.x

Williams, Bruce A.; Delli-Carpini, Michael X. (2011). After broadcast news. Cambridge: Cambridge University Press. ISBN: 9780511846366

Winter, Stephan; Krämer, Nicole C. (2016). "Who's right: The author or the audience? Effects of user comments and ratings on the perception of online science articles". Communications, v. 41, n. 3, pp. 339-360.

https://doi.org/10.1515/commun-2016-0008

Wise, Kevin; Hamman, Brian; Thorson, Kjerstin (2006). "Moderation, response rate, and message interactivity: Features of online communities and their effects on intent to participate". Journal of computer-mediated communication, v. 12 , n. 1, pp. 24-41.

https://doi.org/10.1111/j.1083-6101.2006.00313.x

Wright, Scott; Street, John (2007). "Democracy, deliberation and design: The case of online discussion forums". New media \& society, v. 9, n. 5, pp. 849-869.

https://doi.org/10.1177/1461444807081230

Wu, Shaomei; Hofman, Jake M.; Mason, Winter A.; Watts, Duncan (2011). "Who says what to whom on Twitter". In: Proceedings of the $20^{\text {th }}$ Intl conf on world wide web-WWW'11, p. 705. 
http://www.wwwconference.org/proceedings/www2011/proceedings/p705.pdf

Wu, Tai-Yee; Atkin, David J. (2018). "To comment or not to comment: Examining the influences of anonymity and social support on one's willingness to express in online news discussions". New media and society, v. 20, n. 12, pp. $4512-4532$. https://doi.org/10.1177/1461444818776629

Yang, Shu-Chen; Chang, Wei-Ting; Hsiao, Yi-Ting; Chen, Bo-Yu (2014). "The effects of perceived value on Facebook post sharing intention". In: Procs of the $12^{\text {th }}$ Int conf on advances in mobile computing and multimedia.

https://dl.acm.org/citation.cfm?id=2684171

Yardi, Sarita; Boyd, Dana (2010). "Dynamic debates: An analysis of group polarization over time on Twitter". Bulletin of science, technology \& society, v. 30, n. 5, pp. 316-327.

https://www.danah.org/papers/2010/BSTS-TwitterPolarization.pdf

Zamith, Rodrigo; Lewis, Seth C. (2014). “From public spaces to public sphere”. Digital journalism, v. 2, n. 4, pp. 558-574. https://doi.org/10.1080/21670811.2014.882066

Zhou, Xiang; Chan, Yuen-Ying; Peng, Zhen-Mei (2008). "Deliberativeness of online political discussion: A content analysis of the Guangzhou Daily website". Journalism studies, v. 9, n. 5, pp. 759-770.

https://doi.org/10.1080/14616700802207771

Zhou, Zicong; Bandari, Roja; Kong, Joseph; Qian, Hai; Roychowdhury, Vwani (2010). "Information resonance on Twitter: Watching Iran". Procs of the First workshop on social media analytics - SOMA'10, pp. 123-131.

http://snap.stanford.edu/soma2010/papers/soma2010_17.pdf

Ziegele, Marc; Johnen, Marius; Bickler, Andreas; Jakob, Ilka; Setzer, Till; Schnauber, Alexandra (2013). "Male, hale, comments? Factors influencing the activity of commenting users on online news websites". Studies in Communication and Media, v. 2, n. 1, pp. 110-114.

https://doi.org/10.5771/2192-4007-2013-1-67

Ziegele, Marc; Springer, Nina; Jost, Pablo; Wright, Scott (2017). “Online user comments across news and other content formats: multidisciplinary perspectives, new directions". Studies in communication and media, v. 6, n. 4, pp. 315-332. https://doi.org/10.5771/2192-4007-2017-4-315

Ziegele, Marc; Weber, Mathias; Quiring, Oliver; Breiner, Timo (2018). “The dynamics of online news discussions: Effects of news articles and reader comments on users' involvement, willingness to participate, and the civility of their contributions". Information, communication and society, v. 21, n. 10, pp. 1419-1435.

https://doi.org/10.1080/1369118X.2017.1324505

Zillmann, Dolf; Bryant, Jennings (1985). Selective exposure to communication. Hillsdale, NJ: Lawrence Erlbaum. ISBN: 9780898595857

http://www.bahaistudies.net/asma/selective_exposure-wiki.pdf

La Fundación Biblioteca Social es una institución sin ánimo de lucro que se constituyó en el año 2014. Tiene como objetivo contribuir a compensar los desequilibrios sociales apoyando proyectos que llevan a cabo las bibliotecas públicas, dirigidos a los sectores más vulnerables de la sociedad.

\section{¿Colaboras?}

fundacionbibliotecasocial.org info@fundacionbibliotecasocial.org

э @Biblio_Social

FundacionBibliotecasSocial

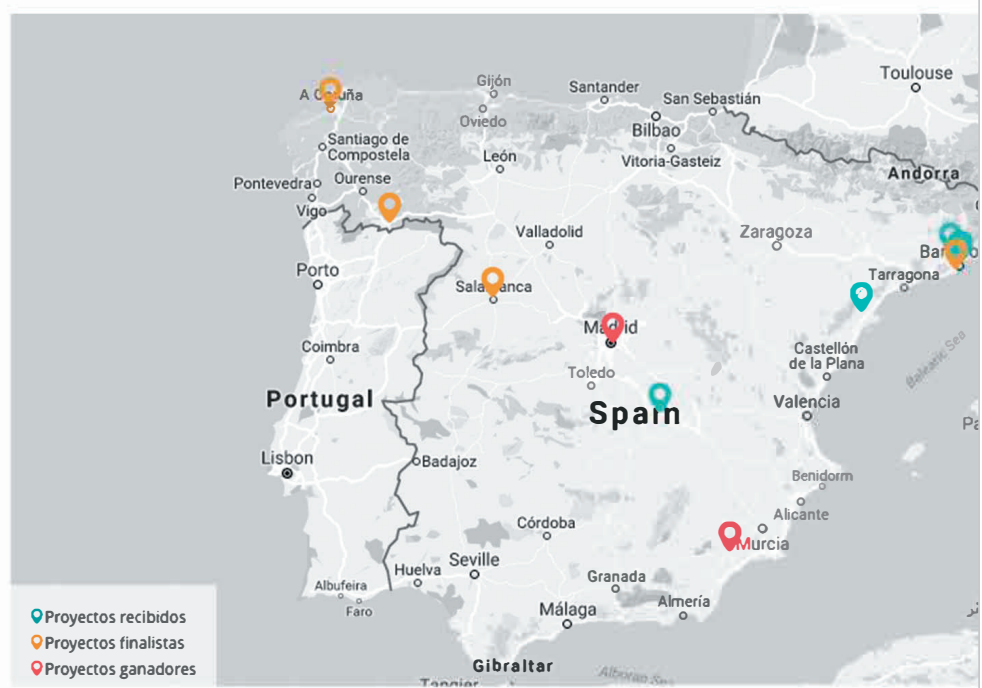

Mapa de proyectos de bibliotecas públicas para la inclusión social. 2016

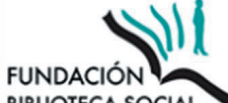




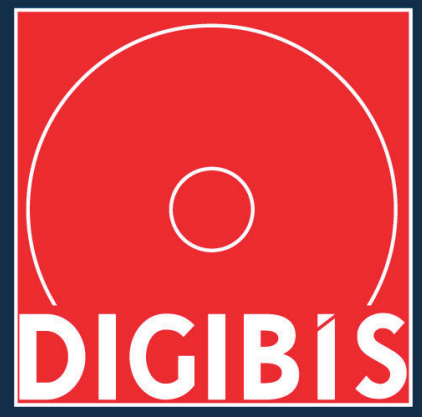

Nuestra vocación: contribuir a que el patrimonio cultural español sea preservado digitalmente y se difunda de la manera más amplia posible

Con metadatos ajustados a la normativa internacional

Aplicaciones Linked Open Data (LOD) con Reconciliación Semántica

Aplicaciones que pueden incorporar Recolector y Repositorio OAI-PMH

Aplicaciones pensadas y desarrolladas para hacer más eficiente y ágil el trabajo de los administradores y más comprensible para el usuario el acceso a los recursos catalogados. 